\title{
Investigating the factors that influence the aroma profile of Apium graveolens: a review
}

Article

Accepted Version

Creative Commons: Attribution-Noncommercial-No Derivative Works 4.0

Turner, L., Lignou, S., Gawthrop, F. and Wagstaff, C. (2021) Investigating the factors that influence the aroma profile of Apium graveolens: a review. Food Chemistry, 345. 128673. ISSN 0308-8146 doi:

https://doi.org/10.1016/j.foodchem.2020.128673 Available at https://centaur.reading.ac.uk/94486/

It is advisable to refer to the publisher's version if you intend to cite from the work. See Guidance on citing.

To link to this article DOI: http://dx.doi.org/10.1016/j.foodchem.2020.128673

Publisher: Elsevier

All outputs in CentAUR are protected by Intellectual Property Rights law, including copyright law. Copyright and IPR is retained by the creators or other copyright holders. Terms and conditions for use of this material are defined in the End User Agreement.

www.reading.ac.uk/centaur 
Central Archive at the University of Reading

Reading's research outputs online 
1 Investigating the factors that influence the aroma profile of Apium graveolens: a review

2

3 Lucy TURNER ${ }^{1}$, Stella LIGNOU $^{1 *}$, Frances GAWTHROP ${ }^{2}$ and Carol WAGSTAFF ${ }^{1}$

4

$5 \quad{ }^{1}$ Department of Food and Nutritional Sciences, University of Reading, Harry Nursten Building, Pepper

6 Lane, Whiteknights, Reading, RG6 6DZ.

$7 \quad{ }^{2}$ A.L. Tozer Ltd, Pyports, Downside Bridge Road, Cobham, KT11 3EH.

8

9 Email:

10 Lucy TURNER (1.turner@pgr.reading.ac.uk)

11 Stella LIGNOU (s.lignou@ reading.ac.uk)

12 Frances GAWTHROP (frances.gawthrop@ tozerseeds.com)

13 Carol WAGSTAFF (c.wagstaff@ reading.ac.uk)

14

$15 *$ Corresponding author: Dr Stella Lignou

16 Phone number: +44 (0) 1183788717

17 


\section{Abstract}

Celery (Apium graveolens) is a regularly consumed vegetable, providing strong, distinct flavours to dishes as well as health benefits. Constituents of the aroma profile of celery include a range of volatile compounds (terpenes, phthalides and aldehydes) that contribute to its characteristic odour and flavour.

Vast amount of research has been completed on the aroma profile of celery. However, there is limited information stating the cultivar, origin and geographical location, despite that research on a plethora of other crops has indicated that these are key factors driving crop performance and quality attributes. This paper characterises the underlying biochemistry that determines the aroma profile of celery, whilst investigating the genetic and environmental influences leading to its variation. We make recommendations for minimum standards (MIAPAE: Minimum Information About a Plant Aroma Experiment) that should be adopted by the scientific community prior to publication of data relating to flavour and aroma characterisation of crops. 


\section{Introduction}

Celery is a member of the Apiaceae or Umbelliferae family, known for the shape of their aromatic flowers called umbels. Crops belonging to this family exhibit distinct flavours including parsley, carrot, fennel, dill and coriander (Terry, 1989). Celery is most frequently used during cooking as well as consumed in its raw state in salads or with condiments (Rozèk, 2007). Celery is thought to be part of the "holy trinity" in many cuisines, combined with bell peppers and onions to form Cajun holy trinity or combined with carrots and onions to form "Soffritto" in Italian cooking.

There are three main subspecies of A. graveolens: leaf celery (Apium graveolens L. subsp. secalinum), stalk celery (Apium graveolens L. subsp. dulce) and root celery, also known as celeriac (Apium graveolens L. subsp. rapaceum). Stalk celery and celeriac are consumed often as vegetables globally, whereas leaf celery or Chinese celery is commonly cultivated and consumed in East Asian countries. Currently on the market, there is an assortment of celery produce available for consumption which is presented in a variety of formats; prepacked whole celery (the celery base, long petioles and leaves, often cut below any knuckles), prepared celery sticks (chopped petioles with no leaves or knuckles) and celery hearts (chopped, with inner petioles; exposing the heart of the celery). Furthermore, celery can be grown as a white, green or pink variety. Varieties can also be found in a range of heights and appearances including noticeable ribs along the petioles, low knuckles or bowing petioles.

Studies have shown that petioles and leaves share similar volatile compounds, however it is often seen that the leaves are much more aromatic than the petioles and a higher yield of essential oil is gained from the leaves (Li, Hou, Wang, Tan, Xu \& Xiong, 2018). Typically, it is the celery petioles that are often consumed in the UK; however, the leaves are consumed in other countries and form part of salads or as a garnish for traditional dishes. Conversely, the aromatic herb coriander, also a member of the Apiaceae family, is used regularly in cooking but the seeds and leaves are utilised.

Celery is a versatile plant grown for many functions; the seed, which commonly undergoes extraction to obtain essential oil, can be used as a flavouring agent but also for medicinal uses. The seed has been reported to have excellent anti-inflammatory and antioxidant potential. Kaufman, Cseke, 
Warber, Duke \& Brielmann (1999) identified over two dozen compounds having the above properties including a range of phthalides, chlorogenic acids, flavonoids (apigenin and luteolin) as well as terpenes. Celery is consumed as a salad vegetable and regularly used as a flavouring agent in stock, soups and bouillons (Malhotra, 2012); its distinct flavour is made up of a combination of volatile compounds that are responsible for the grassy, herbal aroma. These compounds range from aldehydes and esters to terpenes and phthalides, the latter found to contribute most significantly to the characteristic odour of A. graveolens L. (Macleod, MacLeod \& Subramanian, 1988). These compounds, along with low molecular weight sugars, organic acids and flavonoids, are responsible for perceived taste and flavour (Rowan, 2011).

While celery has been the focal point in a plethora of literature reviews, the majority of these have been general reviews and not focused on collating data from previous studies to identify differences in the aroma profile and what may influence this. For example, a widespread and thorough review completed by Sowbhaga (2014) looked at the chemical, technological and nutraceutical functions of celery, however, there was limited focus on the aroma and the impact of variety or different environmental conditions on aroma. Conversely, Li et al. (2018) published a critical review on the advances in celery research providing an in-depth review discussing the current technologies as well as the developments in genetic breeding, genomics research and function genes in celery.

Predominately, research investigating celery flavour utilises the seed or essential oil, with fewer publications looking at the flavour of fresh samples. The flavour profile will change depending on the chemical composition which in turn will change as a result of genotype, season, the part of the plant that is consumed, the geographical region it is grown, the stage and the quality of harvest (Malhotra, 2012) as well as soil type, methods of extraction and analysis of the volatile components. This review aims to examine and elucidate current literature investigating the aroma compounds present in leaf and stalk celery (Apium graveolens L. subsp. secalinum; Apium graveolens L. subsp. dulce), determine how these compounds contribute to flavour and identify factors that play a role in influencing the aroma, thus showing the need for minimum standards to be adopted by the scientific community, allowing for the creation of a repository with potentially replicable and high quality data. 
Table 1: Key words and synonyms used for searching databases.

\begin{tabular}{|c|c|c|}
\hline Main Key word & Synonym & 102 \\
\hline Celery & $\begin{array}{l}\text { - Apium graveolens } \\
\text { - Umbelliferae } \\
\text { - Apiaceae } \\
\text { - Cultivar } \\
\text { - Crop }\end{array}$ & $\begin{array}{l}103 \\
104\end{array}$ \\
\hline Aroma profile & $\begin{array}{ll}\text { - } & \text { Volatile } \\
\text { - } & \text { Essential oil } \\
\text { - } & \text { Flavour } \\
\text { - } & \text { Odour } \\
\text { - } & \text { Terpenes } \\
\text { - } & \text { Phthalides } \\
\text { - } & \text { Secondary metabolites }\end{array}$ & $\begin{array}{l}105 \\
106\end{array}$ \\
\hline Postharvest & $\begin{array}{ll}\text { - } & \text { Maturity } \\
\text { - } & \text { Ripening } \\
\text { - } & \text { Shelf-life } \\
\text { - } & \text { Quality }\end{array}$ & 108 \\
\hline Environment & $\begin{array}{l}\text { - Geographical location } \\
\text { - Season }\end{array}$ & 109 \\
\hline
\end{tabular}

\section{Methodology} sorted in accordance to relevance of the search string used. use (Table 2).

In order to carry out the review, the scientific search engines that were used were Web of Science, ScienceDirect and Google Scholar. Web of Science was mainly used as it offers access to a broader variety of scientific datasets which can be searched singly or simultaneously, including; BIOSIS Previews, Data Citation Index and Food Science and Technology Abstracts (FSTA). Articles were

The following keywords were identified: celery, aroma, postharvest, environment (Table 1). These key words were either used in conjunction or separately. Search operators and search strategies were adopted including key word synonyms, truncation and wildcard symbols in order to help to refine or widen the search. Search strategies were vital for the refinement of the journals used for this review as a vast quantity of journals have previously investigated celery, with close to 3000 journals available for 
Table 2: Key words search results in Web of Science.

113

\begin{tabular}{|l|l|lr|}
\hline Search string & Full text available online & Relevant \\
\hline Celery & 2,925 & 3 & 11 1 \\
\hline Celery aroma profile & 6 & 2 & \\
\hline Volatile content of celery & 11 & 2 & 115 \\
\hline Volatiles of celery essential oil & 25 & 12 \\
\hline Phthalide content of celery & 36 & 13 & 116 \\
\hline Celery postharvest & 16 & 2 & \\
\hline
\end{tabular}

117 There were no limitations on dates of papers used, the majority of papers found were published from 1969-present and references were exported to Mendeley reference manager. Furthermore, peerreviewed journals and journals where access was available through the University of Reading library services were preferred. Originally, papers were considered for evaluation depending on the information they included such as harvest date, cultivar used and cultivar origin, however, this meant many papers were eliminated due to the absence of information of this nature.

\section{Volatile compounds contributing to aroma and flavour}

Within nature, volatiles are comprised of a diverse range of organic compounds that occur naturally, performing multiple functions; from plant and insect signalling through pheromones to food whereby flavour compounds influence organoleptic properties (Pichersky \& Gershenzon, 2002). In plants, a range of biosynthetic pathways occur leading to the formation of different products. It has been identified that agents of primary metabolism are the original precursors for the biosynthetic pathways that lead to volatile synthesis. These include carbohydrates, fatty acids and amino acids (Croteau \& Karp, 1991.; Schwab, Davidovich-Rikanati \& Lewinsohn, 2008). For example, amino acid degradation will lead to the synthesis of phenylpropanes and benzenoids, these are the precursors involved in the synthesis of aromatic alcohols, aldehydes and esters. Whereas in food, flavour compounds can be synthesised through a number of pathways for example, cooking methods such as grilling or roasting, causing the formation of flavour compounds through the Maillard reaction. 
Table 3 shows a collection of volatile compounds including terpenes, alcohols, aldehydes and 137 phthalides that have been identified in celery from published data. This is accompanied by Table 4, which contains the environmental and genotypic data that was included in the studies to build Table 3.

It can be seen in Table 3 that there is a variety of compounds present in celery that contribute to its aroma. Although the vast majority of literature focuses on the terpene and phthalide content, the number of other compounds present in celery including alcohols, esters and aldehydes should not be ignored as these are responsible for fresh, grassy and green notes. The reporting levels of these compounds remain relatively low in comparison to terpenes and phthalides, with (E)-2-hexen-ol, (Z)-3-hexenal, and hexanol only being reported a handful of times.

Completing the review has shown that the aroma compounds present in A. graveolens differ considerably depending on cultivar, geographical location, processing, extraction method and the material used. Table 3 shows the compounds most commonly reported, and these are: limonene (17 times), 3- $n$-butylphthalide (15 times), $\beta$-pinene (14 times), $\alpha$-pinene and myrcene (13 times), $(Z)$ caryophyllene and $\beta$-selinene (12 times). Out of alcohol, ester and aldehyde compounds, the highest reported compound is $(Z)-3$-hexenol ( 6 times) followed by linalool (4 times). Out of the 21 papers, Wilson (1967) and Gold \& Wilson (1963) reported the highest number of aldehydes and alcohols.

Table 4 lists all the various isolation and analysis methods that have been used across the studies to construct Table 3. The most popular method of extraction is hydrodistillation (HD) followed analysis by gas chromatography/mass spectrometry (GC/MS). Although HD is a traditional method of extraction that is regularly used throughout industry, the high temperatures used can contribute to the thermal degradation of some volatile components (Oreopoulou, Tsimogiannis \& Oreopoulou, 2019). Victório, Riehl \& Lage (2009) compared the volatile content using simultaneous distillation-extraction (SDE), HD and static headspace methods on Aplinia zerumbet (Pers). Although they found a difference in the composition of the essential oil between these processes, they concluded that all methods were suitable for the analysis of volatiles, however, SDE is more suitable for analysing smaller quantities of plant material (Victório, Riehl, \& Lage, 2009). 
Table 3: Summary of volatile compounds identified in celery as reported in studies since 1963.

\begin{tabular}{|c|c|c|c|c|c|c|c|c|c|c|c|c|c|c|c|c|c|c|c|c|c|c|c|c|}
\hline \multirow{2}{*}{ Compound Name } & \multirow{2}{*}{ Aroma descriptor ${ }^{a}$} & \multicolumn{22}{|c|}{ Reference $^{b}$} & \multirow{2}{*}{$\begin{array}{c}\text { Concentration } \\
\text { range }(\%)\end{array}$} \\
\hline & & 1 & 2 & 3 & 4 & 5 & 6 & 7 & 8 & 9 & 10 & 11 & 12 & 13 & 14 & 15 & 16 & 17 & 18 & 19 & 20 & 21 & Total & \\
\hline \multicolumn{25}{|l|}{ Aldehydes } \\
\hline hexanal & green, fatty, leafy & & $X$ & & & & & & & $\mathrm{X}$ & & $X$ & & & & & $\mathrm{X}$ & & & & & & 4 & $0.1-2.7$ \\
\hline 3-methylbutanal & $\begin{array}{l}\text { fruity, chocolate, } \\
\text { fatty }\end{array}$ & & $\mathrm{X}$ & & & & & $X$ & & & & & & & & & & & & & & & 2 & $\operatorname{tr}-0.87$ \\
\hline 2-methylbutanal & musty, cocoa, nutty & & $\mathrm{X}$ & & & & & & & & & & & & & & & & & & & & 1 & $0.17-0.45$ \\
\hline furfural & $\begin{array}{l}\text { sweet, almond, } \\
\text { baked bread }\end{array}$ & & $X$ & & & & & & & & & & & & & & & & & & & & 1 & $0.35-1.1$ \\
\hline (Z)-3-hexenal & green & & & & & & & & & & & & $\mathrm{X}$ & & & & $\mathrm{X}$ & & & & & & 2 & $\mathrm{n} / \mathrm{a}$ \\
\hline benzeneacetaldehyde & $\begin{array}{l}\text { honey, floral rose, } \\
\text { sweet }\end{array}$ & & & & $X$ & & & & & & & & & & & & & & & & & & 1 & $\operatorname{tr}-0.13$ \\
\hline heptanal & green, herbal, fatty & & & & & & & & & & & $\mathrm{X}$ & & & & & $\mathrm{X}$ & & & & & & 1 & 0.1 \\
\hline octanal & $\begin{array}{l}\text { citrus, orange peel, } \\
\text { green }\end{array}$ & & & & & & & & & & & $\mathrm{X}$ & & & & & $\mathrm{X}$ & & & & & & 2 & $\operatorname{tr}$ \\
\hline nonanal & $\begin{array}{l}\text { waxy, aldehydic, } \\
\text { fresh }\end{array}$ & & & & $X$ & & & & & & & $X$ & & & & & & & & & & & 1 & $\operatorname{tr}-0.26$ \\
\hline undecanal & waxy, soapy, floral & & & & & & & & & & & & & & & & $\mathrm{X}$ & & & & & & 1 & $\mathrm{n} / \mathrm{a}$ \\
\hline dodecanal & waxy, soapy, citrus & & & & & & & & & & & & & & & & $\mathrm{X}$ & & & & & & 1 & $\mathrm{n} / \mathrm{a}$ \\
\hline citronellal & waxy, floral, herbal & & & & & & & & & & & & & & & & $\mathrm{X}$ & & & & & & 1 & $\mathrm{n} / \mathrm{a}$ \\
\hline (E)-2-nonenal & $\begin{array}{l}\text { green cucumber, } \\
\text { aldehydic }\end{array}$ & & & & & & & & & & & & $\mathrm{X}$ & & & & & & & & & & 1 & $\mathrm{n} / \mathrm{a}$ \\
\hline \multicolumn{25}{|l|}{ Alkane } \\
\hline 2-methylpentane & & & & & & & & & & & & $\mathrm{X}$ & & & & & & & & & & & 1 & 0.1 \\
\hline 3-methypentane & & & & & & & & & & & & $X$ & & & & & & & & & & & 1 & 0.1 \\
\hline hexane & & & & & & & & & & & & $\mathrm{X}$ & & & & & & & & & & & 1 & 0.1 \\
\hline octane & & & & & & & & & & & & $X$ & & & & & & & & & & & 1 & 0.1 \\
\hline nonane & & & & & & & & & & & & $\mathrm{X}$ & & & & & & & & & & & 1 & 0.3 \\
\hline \multicolumn{25}{|l|}{ Alcohols } \\
\hline (Z)-3-hexenol & green & & & & & & & & & & & & $X$ & & & $\mathrm{X}$ & $\mathrm{X}$ & $\mathrm{X}$ & & & $X$ & $\mathrm{X}$ & 6 & $\operatorname{tr}-3.96$ \\
\hline 1-hexanol & green, fruity, apple & & & & & & & & & & & & & & & $X$ & $X$ & $X$ & & & & & 3 & $\operatorname{tr}-0.36$ \\
\hline 2-hexanol & & & & & & & & & & & & & & $X$ & & & & & & & & & 1 & $1.2-1.3$ \\
\hline heptanol & musty, leafy, herbal & & & & & & & & & & & & & & & & $\mathrm{X}$ & & & & & & 1 & $\mathrm{n} / \mathrm{a}$ \\
\hline
\end{tabular}




\begin{tabular}{|c|c|c|c|c|c|c|c|c|c|c|c|c|c|c|c|c|c|}
\hline (E)-2-hexen-ol & $\begin{array}{l}\text { green, leafy, fresh, } \\
\text { grassy }\end{array}$ & & & & & & & & & & & & & $\mathrm{X}$ & & 1 & $\mathrm{n} / \mathrm{a}$ \\
\hline linalool & citrus, floral & & $X$ & & & $X$ & & & $\mathrm{X}$ & & $\mathrm{X}$ & & & & & 3 & $\operatorname{tr}-0.80$ \\
\hline (E)-2,8-p-menthadiene-1-ol & fresh, minty & & & & & $\mathrm{X}$ & & & & & & & & $\mathrm{X}$ & & 2 & $\operatorname{tr}-0.20$ \\
\hline$(Z)-2,8$-p-menthadiene-1ol & fresh & & & & & & & & & & & & & $\mathrm{X}$ & & 1 & $\mathrm{n} / \mathrm{a}$ \\
\hline borneol & $\begin{array}{l}\text { balsam, camphor, } \\
\text { herbal }\end{array}$ & & $\mathrm{X}$ & & & & & & & & & & & & & 1 & 1.4 \\
\hline geraniol & floral, fruity, rose & & $X$ & & & & & & & & & & & & & 1 & 0.6 \\
\hline thymol & $\begin{array}{l}\text { herbal, thyme, } \\
\text { phenolic }\end{array}$ & & $\mathrm{X}$ & & & & $\mathrm{X}$ & & & & & & & & & 2 & $0.70-6.1$ \\
\hline terpinene-4-ol & menthol, woody & $\mathrm{X}$ & & & & & & & $\mathrm{X}$ & & & $\mathrm{X}$ & & & & 3 & $\operatorname{tr}-1.19$ \\
\hline dihydrocarveol & green, minty, sweet & & & & & & & & & & & & & $\mathrm{X}$ & & 1 & $\mathrm{n} / \mathrm{a}$ \\
\hline$\alpha$-terpineol & $\begin{array}{l}\text { citrus, woody, } \\
\text { lemon }\end{array}$ & & & & & & & & $\mathrm{X}$ & & & $X$ & & $\mathrm{X}$ & & 3 & $\operatorname{tr}-0.1$ \\
\hline$(Z)$-carveol & spicy, caraway & & & & & $X$ & & & & & & $\mathrm{X}$ & & $\mathrm{X}$ & & 3 & $\operatorname{tr}-3.4$ \\
\hline carvacrol & $\begin{array}{l}\text { spice, woody, } \\
\text { camphor }\end{array}$ & & & & & & $\mathrm{X}$ & & & & & & & & & 1 & $1.9-3.4$ \\
\hline limonene-1,2-diol & cool, minty & & & & & & & & & & & & & $\mathrm{X}$ & & 1 & $\mathrm{n} / \mathrm{a}$ \\
\hline (E)-carveol & $\begin{array}{l}\text { spicy, caraway, } \\
\text { spearmint }\end{array}$ & & & & & & & & & & & & & $\mathrm{X}$ & & 1 & $\mathrm{n} / \mathrm{a}$ \\
\hline $\begin{array}{l}(E)-p-m e n t h a-1(7), 8 \text {-dien- } \\
\text { 2-ol }\end{array}$ & $\begin{array}{l}\text { camphor, menthol, } \\
\text { phenol }\end{array}$ & & & & & & & & & & & & & $\mathrm{X}$ & & 1 & $\mathrm{n} / \mathrm{a}$ \\
\hline $\begin{array}{l}(E)-1(7) 8 \text {-p-menthadiene- } \\
\text { 2-ol }\end{array}$ & & & & & & & & & & & & & & $\mathrm{X}$ & & 1 & $\mathrm{n} / \mathrm{a}$ \\
\hline eugenol & sweet, warm & & $\mathrm{X}$ & & & $\mathrm{X}$ & & & & & & & & & & 2 & $0.1-3.0$ \\
\hline citronellol & floral, leather, waxy & & & $\mathrm{X}$ & & & & & & & & & & & & 1 & 0.12 \\
\hline Globulol & floral, rose & & & $\mathrm{X}$ & & & & & & & & & & & & 1 & 3.56 \\
\hline Alkene & & & & & & & & & & & & & & & & & \\
\hline$(E, Z)$-undeca-1,3,5-triene & fresh, green, greasy & & & & & & & & $\mathrm{X}$ & $\mathrm{X}$ & & & & & & 2 & $\operatorname{tr}$ \\
\hline pentylcyclohexadiene & & $\mathrm{X}$ & & & & $\mathrm{X}$ & $\mathrm{X}$ & & $\mathrm{X}$ & & & & & & & 4 & $0.2-4.5$ \\
\hline Esters & & & & & & & & & & & & & & & & & \\
\hline 2-octen-1-ol acetate & $\begin{array}{l}\text { green, citrus, } \\
\text { vegetable }\end{array}$ & & & $\mathrm{X}$ & & $\mathrm{X}$ & & & & & & & & & & 2 & $\operatorname{tr}-5.38$ \\
\hline (E)-3-hexenyl-1-acetate & sharp, fruity, green & & & & & & & & & & & & & & $\mathrm{X}$ & 1 & 0.25 \\
\hline carvyl acetate & $\begin{array}{l}\text { green, spearmint, } \\
\text { herbal }\end{array}$ & & & & $\mathrm{X}$ & & $\mathrm{X}$ & $\mathrm{X}$ & & & & & $\mathrm{X}$ & & $\mathrm{X}$ & 4 & $\operatorname{tr}-25$ \\
\hline
\end{tabular}




\begin{tabular}{|c|c|c|c|c|c|c|c|c|c|c|c|c|c|c|c|c|c|c|c|c|c|c|}
\hline bornyl acetate & woody, pine, herbal & & & & & & & $\mathrm{X}$ & & & & & & & & & & & & & 1 & $\operatorname{tr}-0.2$ \\
\hline$\alpha$-terpinyl acetate & $\begin{array}{l}\text { sweet, herbal, } \\
\text { bergamot }\end{array}$ & & $\mathrm{X}$ & & & & & & & & & & & & & $\mathrm{X}$ & & & & & 2 & 0.1 \\
\hline phenylethyl propanoate & $\begin{array}{l}\text { floral, red rose, } \\
\text { fruity }\end{array}$ & & & $\mathrm{X}$ & & & & & & & & & & & & & & & & & 1 & 0.61 \\
\hline (Z)-3-hexenyl pyruvate & green, oily, melon & & & & & & & & & & & & & & & $\mathrm{X}$ & & & & & 1 & $\mathrm{n} / \mathrm{a}$ \\
\hline (E)-pinocarvyl acetate & & & & & & & $\mathrm{X}$ & & & & & & & & & & $\mathrm{X}$ & & & & 1 & $\operatorname{tr}-1.0$ \\
\hline \multicolumn{23}{|l|}{ Monoterpenes } \\
\hline$\alpha$-thujene & woody, green, & $\mathrm{X}$ & $\mathrm{X}$ & & & $\mathrm{X}$ & & & & & $\mathrm{X}$ & & $\mathrm{X}$ & & & & & & & & 5 & $\operatorname{tr}-7.5$ \\
\hline$\alpha$-pinene & fresh, woody & $\mathrm{X}$ & $\mathrm{X}$ & & $X$ & $\mathrm{X}$ & $\mathrm{X}$ & $X$ & & $X$ & $\mathrm{X}$ & & $\mathrm{X}$ & $\mathrm{X}$ & $\mathrm{X}$ & & & $\mathrm{X}$ & $X$ & & 13 & $\operatorname{tr}-9.59$ \\
\hline camphene & citrus, cooling & $\mathrm{X}$ & & & $\mathrm{X}$ & $\mathrm{X}$ & & $\mathrm{X}$ & & & $\mathrm{X}$ & & $\mathrm{X}$ & $\mathrm{X}$ & & & & $\mathrm{X}$ & $\mathrm{X}$ & & 9 & $\operatorname{tr}-0.29$ \\
\hline sabinene & citrus, pine, spicy & $\mathrm{X}$ & & & $\mathrm{X}$ & $\mathrm{X}$ & $\mathrm{X}$ & $\mathrm{X}$ & & $\mathrm{X}$ & $\mathrm{X}$ & & $\mathrm{X}$ & & & & & & & & 9 & $\operatorname{tr}-1.72$ \\
\hline$\beta$-pinene & green, nutmeg, & $\mathrm{X}$ & & & $\mathrm{X}$ & $\mathrm{X}$ & $\mathrm{X}$ & $\mathrm{X}$ & & $\mathrm{X}$ & $\mathrm{X}$ & & $\mathrm{X}$ & $\mathrm{X}$ & $\mathrm{X}$ & & & $\mathrm{X}$ & $\mathrm{X}$ & $\mathrm{X}$ & 14 & $\operatorname{tr}-11.51$ \\
\hline myrcene & balsam, fruity, & $\mathrm{X}$ & $\mathrm{X}$ & $\mathrm{X}$ & $X$ & $\mathrm{X}$ & $\mathrm{X}$ & $X$ & & $X$ & $\mathrm{X}$ & $\mathrm{X}$ & $\mathrm{X}$ & $\mathrm{X}$ & $\mathrm{X}$ & $\mathrm{X}$ & & & $\mathrm{X}$ & & 13 & $\operatorname{tr}-20.97$ \\
\hline$\alpha$-phellandrene & citrus, herbal, green & & & & & & & & & $\mathrm{X}$ & & & $\mathrm{X}$ & & & & & & $\mathrm{X}$ & & 3 & $0.1-0.28$ \\
\hline d-3-carene & citrus, pine, herbal & & & $\mathrm{X}$ & & & & & & & & & & $\mathrm{X}$ & $\mathrm{X}$ & & & & & & 4 & $\operatorname{tr}$ \\
\hline$\alpha$-terpinene & terpenic, pine & & $\mathrm{X}$ & & & & & & & & $X$ & & $\mathrm{X}$ & & & & & & & & 3 & $0.1-0.5$ \\
\hline p-cymene & cumin, lemon & $\mathrm{X}$ & & & & $\mathrm{X}$ & $\mathrm{X}$ & & $\mathrm{X}$ & $\mathrm{X}$ & $\mathrm{X}$ & & $\mathrm{X}$ & & $\mathrm{X}$ & & & & & & 8 & $\operatorname{tr}-0.31$ \\
\hline limonene & citrus, pine, minty & $\mathrm{X}$ & $X$ & $\mathrm{X}$ & $\mathrm{X}$ & $\mathrm{X}$ & $\mathrm{X}$ & $\mathrm{X}$ & $\mathrm{X}$ & $\mathrm{X}$ & $X$ & & $\mathrm{X}$ & $\mathrm{X}$ & $\mathrm{X}$ & $\mathrm{X}$ & & $\mathrm{X}$ & $\mathrm{X}$ & $\mathrm{X}$ & 17 & $\operatorname{tr}-84$ \\
\hline$\beta$-phellandrene & minty, terpenic & & & & & & $X$ & & & & $\mathrm{X}$ & & & & & & & & & & 2 & $\operatorname{tr}-0.6$ \\
\hline$\beta$ - $(E)$-ocimene & sweet, herbal & $\mathrm{X}$ & & & & $\mathrm{X}$ & & $\mathrm{X}$ & & $\mathrm{X}$ & $\mathrm{X}$ & & $\mathrm{X}$ & $\mathrm{X}$ & & & & $\mathrm{X}$ & & & 8 & $0.1-12.50$ \\
\hline$\beta$-(Z)-ocimene & warm, floral, herbal & & & & & $\mathrm{X}$ & $\mathrm{X}$ & $X$ & & $X$ & & & & & & & & & $\mathrm{X}$ & & 5 & $\operatorname{tr}-10.1$ \\
\hline$\gamma$-terpinene & sweet, citrus & $\mathrm{X}$ & $\mathrm{X}$ & & $\mathrm{X}$ & $\mathrm{X}$ & $\mathrm{X}$ & & & $\mathrm{X}$ & $\mathrm{X}$ & & $\mathrm{X}$ & & $\mathrm{X}$ & & & $\mathrm{X}$ & & & 10 & $\operatorname{tr}-78.24$ \\
\hline dihydrocarvone & $\begin{array}{l}\text { herbal, minty, } \\
\text { mentholic }\end{array}$ & & & & & & $\mathrm{X}$ & & & & & & & & $\mathrm{X}$ & & $\mathrm{X}$ & & & & 3 & $\operatorname{tr}-50.0$ \\
\hline L-carvone & $\begin{array}{l}\text { spearmint, herbal, } \\
\text { minty }\end{array}$ & & & & $\mathrm{X}$ & & & & $\mathrm{X}$ & & & & & & & & $X$ & & & & 3 & $0.19-10.0$ \\
\hline p-mentha-1,3,8-triene & $\begin{array}{l}\text { terpenic, } \\
\text { camphoreous }\end{array}$ & & & & & & & & $\mathrm{X}$ & $\mathrm{X}$ & $\mathrm{X}$ & & & & & & & & & & 3 & $\operatorname{tr}-2.3$ \\
\hline \multicolumn{23}{|l|}{ Sesquiterpenes } \\
\hline$\alpha$-copaene & woody, spicy, honey & & & $\mathrm{X}$ & & & & & & & & & $\mathrm{X}$ & & & & & $\mathrm{X}$ & & & 3 & $\operatorname{tr}-0.82$ \\
\hline (E)-caryophyllene & sweet, woody, spice & & & $\mathrm{X}$ & & $\mathrm{X}$ & & $\mathrm{X}$ & & $\mathrm{X}$ & & & & & & & & & & & 4 & $0.1-8.1$ \\
\hline (Z)-caryophyllene & $\begin{array}{l}\text { clove, pepper, } \\
\text { woody }\end{array}$ & $\mathrm{X}$ & $\mathrm{X}$ & $\mathrm{X}$ & $\mathrm{X}$ & & $\mathrm{X}$ & & & & $\mathrm{X}$ & & $\mathrm{X}$ & $\mathrm{X}$ & $\mathrm{X}$ & & & $\mathrm{X}$ & $\mathrm{X}$ & $\mathrm{X}$ & 12 & $\operatorname{tr}-10.5$ \\
\hline$\alpha$-humulene & woody & $\mathrm{X}$ & & & & $\mathrm{X}$ & $\mathrm{X}$ & $\mathrm{X}$ & & & & & $\mathrm{X}$ & & & & & $\mathrm{X}$ & $\mathrm{X}$ & $\mathrm{X}$ & 8 & $\operatorname{tr}-8.3$ \\
\hline ar-curcumeme & & & & & & $\mathrm{X}$ & $\mathrm{X}$ & & & & $\mathrm{X}$ & & & & & & & & & & 3 & $\operatorname{tr}-0.4$ \\
\hline
\end{tabular}




\begin{tabular}{|c|c|c|c|c|c|c|c|c|c|c|c|c|c|c|c|c|c|c|c|c|c|c|c|c|}
\hline$\beta$-selinene & herbal & & $X$ & $X$ & $X$ & $\mathrm{X}$ & & $X$ & $X$ & $X$ & & $X$ & & $\mathrm{X}$ & $\mathrm{X}$ & & & & & $X$ & & $\mathrm{X}$ & 12 & $0.6-16.3$ \\
\hline$\alpha$-selinene & $\begin{array}{l}\text { pepper, orange, } \\
\text { amber }\end{array}$ & & $\mathrm{X}$ & & & $X$ & $\mathrm{X}$ & $\mathrm{X}$ & & $X$ & & $\mathrm{X}$ & & $\mathrm{X}$ & $\mathrm{X}$ & $\mathrm{X}$ & & & & $X$ & & & 10 & $\operatorname{tr}-2.8$ \\
\hline (Z)- $\beta$-guaiene & $\begin{array}{l}\text { woody, spicy, } \\
\text { powdery }\end{array}$ & & & & & & $X$ & & & & & & & & & & & & & & & & 1 & 2.6 \\
\hline cuparene & woody, cedar, floral & & & & $\mathrm{X}$ & & & & & & & & & & & & & & & & & & 1 & $0.64-2.11$ \\
\hline (E)- $\beta$-farnesene & $\begin{array}{l}\text { woody, citrus, } \\
\text { herbal }\end{array}$ & & & & $\mathrm{X}$ & & & & & & $X$ & & & & & & & & & & & & 2 & $0.1-1.27$ \\
\hline kessane & & & & & $\mathrm{X}$ & & $X$ & $\mathrm{X}$ & $X$ & & & $\mathrm{X}$ & & $X$ & & & & & & & & & 6 & $0.6-5.34$ \\
\hline liguloxide & & & & & & & $\mathrm{X}$ & & & & & & & & & & & & & & & & 1 & $\operatorname{tr}$ \\
\hline spathulenol & earthy, herby, fruity & & & $\mathrm{X}$ & $\mathrm{X}$ & & & & & & & & & $X$ & & & & & & & & & 2 & $\operatorname{tr}-4.43$ \\
\hline \multicolumn{25}{|l|}{ Phthalides } \\
\hline alkyl phthalide & & & & & & & & & & & & $X$ & & & & & & & & & & & 1 & $\operatorname{tr}$ \\
\hline 3-butylhexahydrophthalide & celery & & $\mathrm{X}$ & & & & & & $X$ & & & $\mathrm{X}$ & & & & & & & $X$ & & & $X$ & 5 & $\operatorname{tr}-1.2$ \\
\hline 3-n-butylphthalide & $\begin{array}{l}\text { celery, herbal, } \\
\text { phenolic }\end{array}$ & $\mathrm{X}$ & $X$ & $X$ & $X$ & & & $X$ & $\mathrm{X}$ & $\mathrm{X}$ & & $X$ & $X$ & $X$ & $\mathrm{X}$ & $\mathrm{X}$ & $X$ & & $\mathrm{X}$ & & & $\mathrm{X}$ & 15 & $\operatorname{tr}-20.0$ \\
\hline (Z)-3-butylidenephthalide & celery, herbal & $\mathrm{X}$ & $\mathrm{X}$ & $\mathrm{X}$ & & & & & $\mathrm{X}$ & & & $\mathrm{X}$ & & & & $\mathrm{X}$ & $\mathrm{X}$ & & & & & & 7 & $0.1-30.5$ \\
\hline (E)-3-butylidenephthalide & $\begin{array}{l}\text { herbal, lovage, } \\
\text { celery }\end{array}$ & $\mathrm{X}$ & & & $\mathrm{X}$ & & & & & & & $\mathrm{X}$ & & & & & & & & & & & 3 & $1.0-20.1$ \\
\hline cnidilide & celery, herbal & & $\mathrm{X}$ & & & & & & & & & $\mathrm{X}$ & & & & & & & & & & & 2 & $\operatorname{tr}-41.0$ \\
\hline Sedanenolide & herbal & $\mathrm{X}$ & $\mathrm{X}$ & $\mathrm{X}$ & & & & $\mathrm{X}$ & $\mathrm{X}$ & $\mathrm{X}$ & & $\mathrm{X}$ & & $\mathrm{X}$ & & $\mathrm{X}$ & & & & & & & 9 & $0.2-39.5$ \\
\hline$(E)$-sedanolide & herbal, celery & & & & & & & & & & & $\mathrm{X}$ & & & & & & & & & & & 1 & 5 \\
\hline (Z)-sedanolide & herbal, celery & & & & & & & & & & & $\mathrm{X}$ & & & & & & & & & & & 1 & 1.4 \\
\hline (Z)-ligustilide & herbal, celery & & $X$ & & $\mathrm{X}$ & & $\mathrm{X}$ & & $\mathrm{X}$ & & & $X$ & & & & $\mathrm{X}$ & & & & & & & 6 & $\operatorname{tr}-47.31$ \\
\hline sedanolide & herbal, celery & $\mathrm{X}$ & $X$ & & & & & $X$ & $\mathrm{X}$ & $\mathrm{X}$ & & & $\mathrm{X}$ & $X$ & & $\mathrm{X}$ & & & $X$ & & & $\mathrm{X}$ & 11 & $0.2-45.2$ \\
\hline (E)-ligustilide & sweet, spicy & & $X$ & & $X$ & & & & & $X$ & & $X$ & $\mathrm{X}$ & $X$ & $X$ & $\mathrm{X}$ & & & & & & & 9 & $0.1-6.95$ \\
\hline \multicolumn{25}{|l|}{ Other compounds } \\
\hline 2-pentyl furan & green, fruity, earthy & & & & $\mathrm{X}$ & & & & & $X$ & & & & & & $\mathrm{X}$ & & & & & & & 3 & $\operatorname{tr}-0.35$ \\
\hline camphor & camphoreous & & & $\mathrm{X}$ & & & & & & & & & & & & $\mathrm{X}$ & & & & & & & 2 & $\operatorname{tr}-0.6$ \\
\hline pentylbenzene & & & & & $X$ & & & $X$ & & $X$ & & & & & & $X$ & & & & & & & 4 & $\operatorname{tr}-1.84$ \\
\hline 2-undecanone & waxy, fruity, fatty & & & & $X$ & & & & & & & & & & & & & & & & & & 1 & $0.42-0.54$ \\
\hline caryophyllene oxide & sweet, fresh, spicy & & & & $\mathrm{X}$ & & $\mathrm{X}$ & $\mathrm{X}$ & $\mathrm{X}$ & & & & & $\mathrm{X}$ & & & & & & & & & 4 & $\operatorname{tr}-4.11$ \\
\hline apiole & parsley, herbal & & & $\mathrm{X}$ & & & $\mathrm{X}$ & & & $\mathrm{X}$ & $\mathrm{X}$ & & & & & & & & & & & & 4 & $0.1-23.2$ \\
\hline \multicolumn{2}{|c|}{ Total Compounds Identified } & 5 & 28 & 22 & 24 & 11 & 21 & 29 & 25 & 15 & 14 & 40 & 8 & 24 & 13 & 24 & 17 & 12 & 7 & 11 & 10 & 9 & & \\
\hline
\end{tabular}

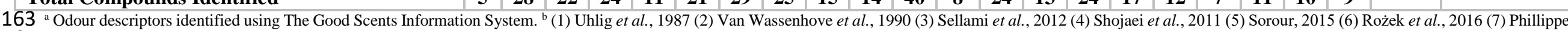

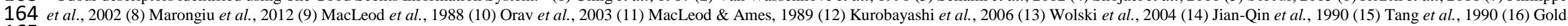
165 \& Wilson, 1963 (17) Wilson, 1967 (18) Wilson, 1970 (19) Ehiabhi et al,. 2013 (20) Deng et al,. 2003. (21) Lund et al, 1973; tr = value was less than 0.1; n/a = data not available. 
Table 4: Summary of Environment x Genotype using the references found in Table 3.

\begin{tabular}{|c|c|c|c|c|c|c|}
\hline $\operatorname{Ref}^{\mathbf{a}}$ & Variety used & Cultivar origin & $\begin{array}{l}\text { Geographical } \\
\text { location of growth }\end{array}$ & $\begin{array}{l}\text { Year(s) } \\
\text { grown }\end{array}$ & $\begin{array}{l}\text { Material } \\
\text { tested }\end{array}$ & Extraction and analysis method \\
\hline 1 & $\begin{array}{l}\text { Utah 52-70, Giant pascal, } \\
\text { Chinese Heug-Kunn, } \\
\text { French dinant, Golden self- } \\
\text { blanching, Camlyn, Florida } \\
\text { 2-14, Clean-cut Harris }\end{array}$ & N/A & Michigan, USA & 1985 & Fresh & $\begin{array}{l}\text { Solvent extraction and separated by HPLC and identified by } \\
\text { GC/MS }\end{array}$ \\
\hline 2 & $\begin{array}{l}\text { Blancato, Avon Pearl, } \\
\text { Golden Spartan, Loret }\end{array}$ & N/A & $\begin{array}{l}\text { Roeselare-Rumbeke, } \\
\text { Belgium }\end{array}$ & $\begin{array}{l}1986 \text { and } \\
1987\end{array}$ & Essential oil & $\begin{array}{l}\text { Extracted by simultaneous steam distillation-extraction (likens- } \\
\text { Nickerson) and identified by high-resolution multi-dimensional gas } \\
\text { chromatography with FID }\end{array}$ \\
\hline 3 & N/A & N/A & Soliman, Tunisia & 2008 & $\begin{array}{l}\text { Essential oil } \\
\text { and fresh }\end{array}$ & $\begin{array}{l}\text { Extracted with solvent extraction and hydrodistillation and } \\
\text { identified using GC/FID }\end{array}$ \\
\hline 4 & Wild Type & N/A & $\begin{array}{l}\text { Koohrang, Bazoft } \\
\text { and Samsami, Iran }\end{array}$ & 2008 & Essential oil & Extracted by hydrodistillation and identified using GC/MS \\
\hline 5 & N/A & N/A & $\begin{array}{l}\text { Agriculture Research } \\
\text { Centre, Egypt }\end{array}$ & 2013 & $\begin{array}{l}\text { Fresh and } \\
\text { dried }\end{array}$ & Extracted by hydrodistillation and identified using GC/MS \\
\hline 6 & Safir & Netherlands & Lublin, Germany & 2019 & Fresh & Extracted by steam distillation and identified using GC/MS/MS \\
\hline 7 & Gaudich & Punjab, India & $\begin{array}{l}\text { Kanpur and Punjab, } \\
\text { India }\end{array}$ & N/A & $\begin{array}{l}\text { Celery seed } \\
\text { oil }\end{array}$ & Oils sourced for the study and identified using GC/MS \\
\hline 8 & N/A & Europe & Italy and Portugal & N/A & Fresh & $\begin{array}{l}\text { Extracted by SFE and hydrodistillation and identified using } \\
\text { GC/FID and GC/MS }\end{array}$ \\
\hline 9 & N/A & Libya & Libya, brought fresh & N/A & Fresh & $\begin{array}{l}\text { Extracted by steam distillation and identified using GC/FID and } \\
\text { GC/MS }\end{array}$ \\
\hline 10 & N/A & Estonia & Brought fresh & N/A & $\begin{array}{l}\text { Fresh and } \\
\text { air-dried } \\
\text { essential oil }\end{array}$ & Extracted by SDE and identified by capillary GC and GC/MS \\
\hline 11 & Celebrity & N/A & Brought fresh & N/A & Fresh & $\begin{array}{l}\text { Extracted by high vacuum-low temperature distillation and } \\
\text { identified using GC/GC/FID, GC/MS and GC/OPA }\end{array}$ \\
\hline
\end{tabular}




\begin{tabular}{|c|c|c|c|c|c|c|}
\hline 12 & N/A & N/A & $\begin{array}{l}\text { Nagano Prefecture, } \\
\text { Japan brought fresh }\end{array}$ & N/A & Fresh & $\begin{array}{l}\text { Extracted by hydrodistillation followed by SAFE and identified } \\
\text { using GC/FID, GC/MS and }\end{array}$ \\
\hline 13 & N/A & N/A & N/A & N/A & Fresh & Extracted by solvent extraction and identified using GC/ITMS \\
\hline 14 & N/A & N/A & N/A & N/A & $\begin{array}{l}\text { Celery seed } \\
\text { oil }\end{array}$ & $\begin{array}{l}\text { Extracted by steam distillation and identified using GC/MS and } \\
\text { GC/FTIR }\end{array}$ \\
\hline 15 & N/A & N/A & Brought fresh & N/A & Fresh & Solvent extraction and identified using GC and GC/MS \\
\hline 16 & N/A & N/A & Brought fresh & N/A & Celery juice & $\begin{array}{l}\text { Extracted by steam distillation, fractions were collected in portions } \\
\text { of the apparatus (column-bottom, chilled water trap, ice trap, salt } \\
\text { and ice trap, dry-ice trap and liquid nitrogen trap). Identified using } \\
\text { GC, GC/FID and GLC }\end{array}$ \\
\hline 17 & N/A & N/A & N/A & N/A & Essential oil & $\begin{array}{l}\text { Extracted by batch and continuous steam distillation followed by } \\
\text { solvent extraction, and identified using GC/MS F\&M }\end{array}$ \\
\hline 18 & N/A & N/A & N/A & N/A & Essential oil & $\begin{array}{l}\text { Extracted by batch and continuous steam distillation, identified } \\
\text { using GC/MS }\end{array}$ \\
\hline 19 & N/A & N/A & Nigeria & N/A & Essential oil & Extracted by hydrodistillation and identified using GC/MS \\
\hline 20 & N/A & N/A & $\begin{array}{l}\text { Research Centre for } \\
\text { Plants, Shenghai }\end{array}$ & N/A & Fresh & HS-SPME-GC/MS was using for extraction and identification \\
\hline 21 & Utah 5270 and Flormart & & Florida & $\begin{array}{l}\text { November } \\
1972, \text { April } \\
\text { and July } \\
1973\end{array}$ & Essential oil & $\begin{array}{l}\text { Extracted by steam distillation, volatile content determined by } \\
\text { "Bromate Titration Method" and were separated using GLC. }\end{array}$ \\
\hline
\end{tabular}


Using a method where volatiles can be isolated from a matrix at room temperature under a vacuum, will prevent thermal degradation of compounds and improve recovery rates. MacLeod and Ames (1989) used low temperature high vacuum distillation and identified 40 compounds including 13 monoterpenes, 12 phthalides and five sesquiterpenes as well as several alcohols, alkenes and alkanes. Utilising high vacuum distillation allows for the separation of higher boiling compounds such as phthalides, which has been shown to be difficult to isolate and characterise in previous studies shown by Orav, Kailas and Jegorova (2003). Here six phthalides isomers were identified but the correct characterisation of these isomers could not be completed.

In terms of analysis, the majority of the studies (Table 4) used 1D GC in order to analyse celery volatiles. However, with this method, correct characterisation of phthalides was shown to be limited and even in some studies, no phthalides were identified. The utilisation of 2D GC has shown to aid in the correct separation of phthalides as well as the characterisation of phthalide isomers (Bartschat, Beck, \& Mosandl, 1997; MacLeod \& Ames, 1989; van Wassenhove et al., 1990).

Only one study by Deng, Song, Zheng, Hu \& Zhang (2003) analysed fresh celery samples by extracting the volatiles present in the headspace using solid phase micro-extraction (SPME) followed by GC/MS. However, investigating celery as an essential oil has shown to yield results with more identifiable compounds than SPME as shown by MacLeod and Ames, (1989); van Wassenhove et al.,(1990); Philippe et al.,(2002); Shojaei et al.,(2011) (Table 3, reference 11, 2, 4 and 7).

Orav et al., (2003) and Sorour, Hassanen and Ahmed (2015) compared the differences in volatile content between fresh and dried celery material and concluded that processing the celery through methods such as freeze drying or air drying should not alter the presence of aroma compounds but only the abundance of certain compounds. This was confirmed by Orav et al., (2003) who investigated the difference of aroma profiles in fresh celery and air dried, oven dried and freeze-dried celery, showing that there was little difference between the processing methods in terms of the presence or absence of compounds; but differences were observed in terms of the concentrations of certain compounds (e.g. a decrease in limonene and a slight increase in phthalide concentration). 
Table 3 also shows the variation in \% composition between compounds. Although variation is expected when so many variables are involved, certain compounds show a extreme variation; the biggest occuring within the monoterpenes, particularly for limonene and $\gamma$-terpinene. Both of these compounds have been identified to be very common monoterpenes in celery as shown by van Wassenhove et al. (1990), identifying limonene and $\gamma$-terpinene as the most abundant compounds across four varieties. A possible cause of this variation could be due to the influence of abiotic and biotic factors, such as maturity and environment, have upon these compounds. Thus, showing the importance of examining the same cultivar across different seasons in different geographical locations. Although not as vast, variation between the reported composition of phthalides can be seen, particularly with cnidilide, (Z)-ligustilide and sedanolide. Characterising phthalides and their enantiomers correctly have been shown to difficult using 1D GC and hydrodistillation techniques, this could explain the variation between extraction processes.

Furthermore, out of the 21 papers that were used to build Table 3, 13 papers mentioned the geographical region the cultivar under investigation was grown, seven provided the celery cultivar name, seven provided growing and harvesting dates, five mentioned the cultivar origin, three completed a multisite experiment, three used more than one cultivar and only one repeated the experiment the following year (Table 4). Not one paper used one single cultivar in a multisite experiment that was repeated the following season. The vast quantity of research that has been completed on celery and its aroma profile can only be described as partial and inconclusive. Clearly, there is variation in the aroma profile and simply studying one cultivar, grown in one location, in one year is not a sufficient sample size or experiment to conclude the following compounds are the only compounds to be present in celery. There was no compound that was detected in every study on celery.

It is clear from Table 4 that many authors do not record basic information regarding the provenance of their samples, this would enable some consideration of the genetic and environmental influences on aroma compounds. Other communities have developed standards for minimum information required for characterising raw materials used in experimental datasets and it is recommended that the flavour science community also adopts a similar approach. 
Plant phenotyping experiments, and it could be argued that flavour and aroma are a subset of 223 phenotype, are already required to adhere to standards. The proposed guidelines for the correct handling of data from plant phenotyping experiments to allow for data reuse and combining are known as the "Minimum Information About a Plant Phenotyping Experiment” (MIAPPE). These guidelines contain a checklist of attributes that would aid in the understanding of the plant phenotypic data and how it was obtained. The checklist of attributes can be categorised into the following sections: general metadata, timings and locations, environments, treatments, experimental design, sample collection and processing and observed variables (Ćwiek-Kupczyńska et al., 2016). Similarly, MIAME: Minimum Information About a Microarray Experiment present six fundamentals that enable the correct interpretation of results and experimental repetition including: the raw data for each hybridisation as well as the final processed data for the set of hybridisations, essential sample annotation (experimental factors), experimental design, annotation of the array and essential protocols (laboratory and data processing) (Brazma et al., 2001).

Following a similar attribute checklist to MIAME and MIAPPE, Table 5 presents MIAPAE: 'Minimum Information About a Plant Aroma Experiment', describing the minimal information that would allow for accurate interpretation and correct repetition of the experiment. Including the attributes presented in Table 5 allows for sufficient information to be provided, ensuring experiments whereby the aroma of plants is profiled can be interpreted, verified and repeated correctly, with the ultimate goal of facilitating the formation of superior datasets. 
Table 5: Recommended attribute checklist for plant aroma experiments.

\begin{tabular}{|c|c|c|}
\hline Checklist section & Attribute & Recommended information to include \\
\hline \multirow[t]{2}{*}{ Experimental design } & Field & Replication, block design, harvest protocol \\
\hline & Laboratory & $\begin{array}{l}\text { Replication, analysis protocol including extraction protocol, use of standards, } \\
\text { temperature programs, QCs and statistical analysis used }\end{array}$ \\
\hline \multirow[t]{3}{*}{ Sample information } & Seed & Preparation, source, pre-treatments \\
\hline & Plant & Taxon, common name, origin, cultivar, age and life stage at harvest \\
\hline & Plant extract & Type of extract used e.g. essential oil, fresh or dried material \\
\hline \multirow[t]{2}{*}{ Timing and location } & Timing & $\begin{array}{l}\text { Start and duration of experiment, timings between the stages of harvest and } \\
\text { processing }\end{array}$ \\
\hline & Location & Growth, post-harvest, processing and storage location \\
\hline \multirow[t]{4}{*}{ Environment } & Met data & Average day and night temperature $\left({ }^{\circ} \mathrm{C}\right)$, rainfall $(\mathrm{mm})$, day and night length (hours) \\
\hline & Agronomic practices & Treatments, watering and irrigation $(\mathrm{L})$ \\
\hline & Nutrients & Fertiliser composition and amount added, soil salinity \\
\hline & Postharvest & $\begin{array}{l}\text { Temperature of storage }\left({ }^{\circ} \mathrm{C}\right) \text {, transport between facilities, processing and storage } \\
\text { conditions }\end{array}$ \\
\hline \multirow[t]{3}{*}{ Raw material collection, processing and storage } & Collection & Plant organ of interest, method of collection \\
\hline & Processing & Method of processing, duration, location and temperature \\
\hline & Storage & Method of storage, duration, location and temperature \\
\hline
\end{tabular}


The variation in compounds identified in celery between experiments investigating the aroma profile can be seen clearly (Table 3) and with different cultivars, experimental designs, processing methods and instrumental analysis, however, it is difficult to compare these results. Using the proposed MIAPAE standards, whereby information on the experimental design, sample collection, processing and testing is included, experiments can either be replicated or variables changed/introduced to allow for further comparison, collation of datasets and eventually leading a possible public repository with the purpose of providing high-quality plant aroma data.

\subsection{Terpenes}

The aroma of raw celery is often described as fresh, herbal, woody and citrusy, and the main contributors to these descriptors are terpenoids, sesquiterpenes and monoterpenes. These are all major components that constitute the aroma profile in celery, as well as ubiquitous across many other flowers, herbs, spices and food stuffs. Terpenes play a diverse range of roles in nature and in industry, from insect and plant signalling to fragrances and flavourings.

Terpenes are mostly hydrocarbons and are constituents of essential oils. Isoprene, a unit made up of five carbons, is the building block for terpene synthesis and when biosynthesis occurs, isoprene forms either acyclic, cyclic or polycyclic compounds (Parker, 2015). Celery contains a range of monoterpenes, two isoprene units $\left(\mathrm{C}_{10} \mathrm{H}_{16}\right)$, and sesquiterpenes, made up of three isoprene units $\left(\mathrm{C}_{15} \mathrm{H}_{24}\right)$ and these can be cyclic or bicyclic in structure, including: isoprene, limonene, $\beta$-pinene, $\beta$-selinene and $\beta$ caryophyllene. The structure of $\beta$-caryophyllene includes a nine-membered ring that is fused to a cyclobutene ring (Fig. 1).

$<$ Insert Figure 1>

Biosynthesis of terpenes occurs from isopentane either through the mevalonic acid pathway (appendix 1, schematic 1) (MVA-pathway) from acetyl-CoA or the non-mevalonate pathway (appendix 1, schematic 2). During the MVA-pathway, the pyrophosphorylation of mevalonic acid leads to the production of mevalonic acid pyrophosphate (MVA-PP), decarboxylation and dehydration of MVA-PP will result in the formation of isopentenyl diphosphate (IPP). IPP can be isomerized to produce 
dimethylallyl diphosphate (DMAPP). The bonding of IPP with DPP leads to the synthesis of geranyl pyrophosphate (GPP), which is the precursor of monoterpenes, and then the bonding of a further IPP molecule forms farnesyl pyrophosphate, the precursor of sesquiterpenes (Schwab et al., 2008). Alternatively, isoprene can also be synthesised through the non-mevalonate pathway or the MEP/DOXP, which similarly to the MVA-pathway, leads to the production of IPP and DPP. However, the MEP/DOXP-pathway occurs more predominantly in green plants, operating in the plastids, utilising D-glyceraldehyde 3-phosphate bonding with pyruvate to form 1-deoxy-D-erythritol (DXP). This eventually leads to the production of DMAPP, IPP and GPP to synthesise predominantly monoterpenes and some sesquiterpenes. In contrast, the MVA-pathway operates in the cytosol and synthesises mostly sesquiterpenes, sterols and triterpenes (Kuzuyama \& Seto, 2012).

Within A. graveolens, there has been a wide range of terpenes reported in literature including a variety of monoterpenes and sesquiterpenes. Monoterpenes such as d-limonene (62.4-70.3\%) and (I)$\beta$-ocimene (10.1-10.5\%) contributed the largest proportion of volatiles present in fresh celery grown in Estonia (Orav et al., 2003) (Table 3, reference 10), whereas, Jian-Qin et al. (1990) (Table 3, reference $14)$ identified in celery seed oil d-limonene (72.16\%), $\beta$-selinene $(12.17 \%)$ and $\alpha$-selinene $(2.05 \%)$ as the most abundant terpenes.

Limonene $(18,000-37,000 \mu \mathrm{g} / \mathrm{kg}), \lambda$-terpinene $(6,000-16,500 \mu \mathrm{g} / \mathrm{kg})$ and $\beta$-pinene $(436-1,205$ $\mu \mathrm{g} / \mathrm{kg}$ ) were most abundant across the four varieties used in an investigation carried out by Van Wassenhove et al. (1990) using blanching varieties grown in Belgium (Table 3, reference 2). The variation across the four cultivars used in this study provides evidence that there is a genetic basis for flavour deviation between cultivars. Throughout literature, it can be seen that limonene is the most abundant terpene, with an odour often described as citrus, fresh and lemon. However, limonene is not a key characteristic aroma compound, with a reported odour threshold range of $0.50-0.59 \mathrm{ppb}$ orthonasal and 0.46-0.62 ppb retronasal (Plotto, Margaría, Goodner, Goodrich \& Baldwin, 2004).

A study carried out by Deng et al., (2003) utilised SPME GC/MS to analyse the volatile constituents making up celery, identifying many compounds including monoterpenes and terpenoids. 
Obtaining a cultivar grown in Shanghai, Deng et al. (2003) confirmed the high proportion of limonene present (32.22\% relative contents), followed by $\alpha$-pinene (16.56\% relative contents), and $\beta$-ocimene (9.59\% relative contents). These values differ considerably when comparing literature (Table 3) suggesting that multiple factors play a role in celery flavour including geographical location and cultivar (Deng et al., 2003).

\subsection{Phthalides}

Phthalides are naturally sourced in plants, being particularly abundant in Ligusticum and Angelica from the Apiaceae family (Karmakar, Pahari \& Mal, 2014). Celery, celeriac and lovage are rich sources of phthalides and these compounds hold many health benefits; they are biologically active compounds playing roles on the central nervous system and cardiac performance, aiding in anti-thrombotic modulation and providing protection against cerebral ischaemia and high blood pressure (Lin, Chan, Chung, \& Li, 2005). In 2002, synthesised $d l-3-n$-butylphthalide, established from 3- $n$-butylphthalide, was approved by the China Food and Drug Administration as a new drug for the treatment of strokes. Previous research shows a significant increase of cerebral blood flow in cerebral ischemia rats when $d l$ 3-n-butylphthalide was used as treatment (Yan, Feng \& Zhang, 1998). More recently, a 90-day administration of $d l-3-n$-butylphthalide was completed, whereby the administration of $d l-3-n-$ butylphthalide had significantly more favourable outcomes than Ozagrel, a drug commonly used to treat strokes (Cui et al., 2013).

Structures and biosynthetic pathways of phthalides have been suggested previously but they remain ambiguous and little is actually known about these compounds. One possible pathway way has been suggested by Karmakar et al. (2014) (appendix 1, schematic 3). They hypothesised that phthalide is originally synthesised from tetraketide (2) which in turn, is formed from the condensation of four acetic acid units (1) bonded by the action of polyketide synthase. According to Karmakar et al. (2014), dialdehyde (8) is synthesised through the condensation of the tetraketide unit to orsellinic acid (3) though various enzymes (ketoreductase, cyclases and aromatases). Then, orsenllic acid is subject to methylation, regiospecific oxidation and decarboxylation (4-7). An intramolecular Cannizzaro reaction (9) occurs producing phthalide (10) from dialdehyde. Phthalides are classified according to their 
substitution at C-3 and the oxidation occurring within the benzene ring (Karmakar et al., 2014). This can be seen in Figure 1, where the double bonds within the benzene ring change along with the arrangement present at C-3 to produce a different compound.

To date, all naturally occurring phthalides are derived from 1(3H)-isobenzofuranone consisting of one benzene ring bonded with a $\gamma$-lactone between carbon atoms. $1(3 H)$-Isobenzofuranone has the most simple phthalide structure, $\mathrm{C}_{8} \mathrm{H}_{6} \mathrm{O}_{2}$ (Lin et al., 2005). Multiple phthalides have been identified in celery including: phthalide, 3-butylphthalide, 3-butylidenephthalide, (Z)-ligustilide and sedanenolide (Fig. 1).

Using enantioselective multidimensional gas chromatography, Bartschat, Beck \& Monsandl (1997) analysed 3-butylphthalide enantiomers and eight 3-butylhexahydrophthalide stereoisomers in celery, celeriac, celery seed and fennel extracts. From this, 3-butylphthalide enantiomers ( $3 S$ and $3 R$ ) were identified with $3 S$ enantiomer showing to be the preferred configuration in all extracts. Furthermore, 3-butylhexahydroxyphthalides $(3 R, 3 \mathrm{a} R, 7 \mathrm{a} S$ and $3 S, 3 \mathrm{a} R, 7 \mathrm{a} S)$ were detected and shown to be generated in high enantiomeric purity in celery and celeriac extracts. Bartschat et al. (1997) stated that the high enantiomeric purities of these compounds suggest that they may be synthesised with high stereoselectivity; originating from partially hydrogenate phthalides such as sedanolide and sedanenolide, known key contributors to A. graveolens odour.

Often in literature, the stereochemical aspects of these phthalide compounds have been neglected including the impact these have upon sensory characteristics. MacLeod and Ames (1989) analysed the volatile components present in supermarket purchased celery and celeriac using GC, GC/MS and GC odour port assessment (GC/OPA) and positively identified 12 phthalides in both extracts including two 3-butylhexahydrophthalide isomers. Although the stereochemistry was not taken into consideration, these two isomers were shown to possess different odours according to GC/OPA. The first isomer identified exhibited a "sweet, sickly, cooked celery" and "braised celery, peppery, smoky" in celery and celeriac respectively. The second isomer was not identified in celery but was described as "celery, fruity, fragrant" in celeriac. MacLeod and Ames (1989) discussed how having a substitution of an alkyl group at $\mathrm{C}_{3}$ would lead to a less celery odour compared to an alkylidene substitution whereby a more intense celery odour due to the alkylidene group increased from $\mathrm{C}_{1}$ to $\mathrm{C}_{4}$. This is in agreement with 
findings by Gold \& Wilson (1963) who identified four alkylidene phthalides in celery juice distillate fractions that possessed a strong characteristic celery odour and were identified as the principal odour components of celery.

There has been conflicting evidence on whether phthalides are truly present as earlier studies were unable to separate and characterise phthalide compounds including 3-butylhexahydroxyphthalides enantiomers and the sedanolides. Uhlig et al. (1987) investigated the effect of phthalides on the flavour of celery using eight different cultivars of varying origins but grown in Grand Rapids, Michigan (Table 3, reference 1). DCM extracts of celery stem tissue were separated by HPLC and identified using GC/MS. The peak area per gram of total solids of butylphthalides (butylphthalide, trans- and cisbutylidene phthalide), sedanenolide and sedanolide were identified. Sedanolide was absent in six out of eight cultivars tested and they suggested that this result could be due to technical error, as the HPLC was unable to resolve minute quantities of sedanolide from sedanenolide. Within the cultivars, there was over six-fold variation in the abundance of different compounds, with butylphthalide abundance ranging from 250 to 1540 peak area per g total solids (Uhlig et al., 1987). In Uhlig's study, five phthalides were identified, almost half of the phthalides identified by MacLeod and Ames (1989).

For sensory evaluation, Uhlig presented the plant tissue from the samples diluted in water to six trained panellists, whereby the intensity of celery flavour was evaluated on a nine-point hedonic scale $(1=$ no celery flavour and $9=$ extremely strong celery flavour). These flavour scores were correlated with the phthalide content, leading Uhlig to conclude that the variation of phthalide content across cultivars resulted in significant differences in the perception of celery flavour (Uhlig et al., 1987).

Phthalides, although lower in abundance in than terpenes, are much more odour-active, exhibiting flavour dilution factors of around 15,000 before the limit of detection is reached and can be seen to be characteristic compounds of celery aroma (Kurobayashi et al., 2006). Sedanenolide has an odour threshold value of $0.14-0.60$ ppm depending on the enantiomer (Oguro and Watanable, 2011) and 3n-butylphthalide has a value of 0.00001 ppm (Bartschat, Maas, Smietana \& Mosandl, 1996). Furthermore, Lund, Wagner \& Bryan (1973) identified the odour threshold of phthalide compounds that expressed a celery-like odour. These included sedanolide (1 ppm), 3-n-butylphthalide (10 ppm) 
and hexahydro-3-n-butylphthalide (2 ppm) as well as $\beta$-selinene (1 ppm), although the latter were identified to not exhibit a characteristic celery odour when compared with sedanolide and 3- $n$ butylphthalide, they were still considered to be contributors to the fresh celery aroma. Out of these compounds, sedanolide was identified as the most characteristic compound to the celery odour.

\subsection{Alcohols, aldehydes and esters}

In plants, alcohols, aldehydes and esters originate from saturated and unsaturated fatty acids such as linolenic acid and are formed predominately by three processes: $\alpha$-oxidation, $\beta$-oxidation and the lipoxygenase pathway. Initially, saturated and unsaturated fatty acids are bound to acyglycerols as triacylglycerides and are released as free fatty acids via enzymatic oxidative (acyl hydrolase) degradation of lipids. The lipoxygenase pathway, which leads to the synthesis of short-chain aldehydes and alcohols $\left(\mathrm{C}_{6}\right.$ and $\left.\mathrm{C}_{9}\right)$, involves multiple enzymes including lipoxygenase (LOX), hyperoxide lyase (HPL) and alcohol dehydrogenase (ADH). LOX catalyses the conversation of linolenic acid to 9hydroperoxide or 13-hydroperoxide.

With the use of enzymes or $\beta$-oxidation; aroma compounds are formed such as 3-(Z)-hexenol, $(E)$ jasmone and 3-(Z)-hexenyl acetate. For example, hexanal is a linolenic acid-derived aldehyde with a fatty, green odour, it is synthesised through a series of enzymatic reactions using LOX, HPL, 3Z,2Eenal isomerase and alkenal oxidoreductase (Schwab \& Schreier, 2002; Stumpe \& Feussner, 2006). Figure 1 shows the compound structure for: (Z)-3-hexenyl pyruvate, (Z)-3-hexen-1-ol, linalool and (Z)3-hexenal, these are just a selection of alcohols, aldehydes and esters that have been identified in celery. Compounds known as green leaf volatiles (GLVs) are synthesised in the plant when subject to biotic and abiotic stresses. These include compounds such as 3-(Z)-hexanol, 3-(Z)-hexenyl acetate and hexanal, these compounds often have green, fatty odours, important to celery aroma.

Few published papers focus on the presence of other volatiles such as alcohols, esters and aldehydes. These compounds are vital to the aroma, with odours described as green, fresh, citrus and floral. Shojaei et al. (2011) studied the chemical composition of three ecotypes of wild celery (Bazoft, Koohrang and Samsami) grown in three different regions of Iran in 2008 and identified a range of aromatic compounds using GC-MS analysis (Table 3, reference 4). Within the three ecotypes, at least 

22 compounds were identified and phthalides made up the majority of the chemical composition.

407 Compounds such as 2-octen-1-ol acetate, pentylbenzene and 2-undecanone were reported at much lower abundances, yet at similar concentrations to sesquiterpenes. Gold and Wilson (1963) investigated the volatile flavour substances present in celery juice, identifying 38 compounds comprising of aldehydes, esters, alcohols, terpenes and phthalides (Table 3, reference 16). Gold and Wilson identified the ester (Z)-3-hexenyl pyruvate as a principle odour constituent using a dry ice trap, with odour descriptors such as green, vegetative and floral green tea (Gold and Wilson, 1963).

Wilson (1967) identified and quantified the alcohol composition of celery essential oil using column chromatography on two celery essential oils. Using this method of separation allowed him to identify that the two essential oils were comprised of 10 to $15 \%$ alcohol, including hexan-1-ol, (Z)-3-hexene-1ol and (E)-2-hexene-1-ol as well as terpene alcohols; $(E)$ - and (Z)-2,8-p-menthadiene-1-ol (Table 3, reference 17). He concluded that although these alcohol compounds did not possess aromas that were typical of celery, they were still important contributors to the overall aroma and flavour (Wilson, 1967).

\section{Genetics and the aroma of celery}

Over the years, there has been a focus on improving yield to increase product availability as well as to decrease cost paid by the consumer. However, this means that there has been a lack of focus on the quality of crops and therefore, important traits such as flavour have been ignored. Key aspects of quality include nutritional content, post-harvest quality, being free of disease and eating quality. There has been a lot of focus on developing disease-resistant celery lines, particularly to Fusarium yellows (Fusarium oxysporum f. sp. apii) which is one of the biggest diseases to threaten celery production worldwide. It was Orton, Hulbert, Durgan \& Quiros (1984) who developed the first Fusarium-resistant celery line using a celeriac accession (Orton et al., 1984). Furthermore, breeding of late bolting or slow bolting variety has also been emphasised to improve yield, particularly during the winter-spring season to extend the season (Li et al., 2018).

There are multiple reasons as to why emphasis on breeding for flavour has been low. Breeders carry out taste tests during the development phase whereby taste attributes such as bitterness and 
sweetness are scored, and lines are rejected if unpalatable. Nevertheless, breeders do not have the tools available to select for flavour, in addition to the need to select for the maintenance and consistency of flavour (Klee, 2010). Determining the flavour would require sensory profiling analysis to be completed on a whole breeding population using a trained panel, as well as laboratory work to identify and quantify the aroma compounds present. This can be a lengthy and expensive process. Using transcriptome sequencing could help identify genes that are being expressed in the same cultivar that has been taken into different environments and grown, providing information on the differences in gene expression. However, genetics only show the potential flavour of the crop, factors such as the environment, handling and damage and cooking will alter the flavour profile and taste (Klee, 2010).

Conversely, work completed by Thappa et al. (2003) investigating the variation of aroma compounds in celery seed and leaf oil, particularly focused on reducing the limonene and increasing the phthalide content to improve the flavour quality for consumption. Although this study concentrated on seed varieties, the success in producing a genetically improved celery expressing a reduced limonene content shows that A. graveolens can be modified to exhibit desired properties (Thappa et al., 2003).

Although there have been advances in biotechnology, the celery genome remained unconstructed only until recently, whereby previously, the genome of the carrot was the only member of the Apiaceae family with the genome constructed. Li et al. (2020) reported the genome sequence of A. graveolens $L$. with a total sequence length of $2.21 \mathrm{~Gb}$ and 34,277 predicted genes which is larger than the carrot sequence. The completion of this work allowed Li et al. (2020) to identify significant genes involved in disease resistance and secondary metabolite synthesis and metabolism. Focusing on terpenoid synthase family genes, three developmental stages were monitored using previous transcriptome data to analyse the expression of these terpenoid synthase proteins. During the first two stages of development, these proteins were seen to be expressed at a higher abundance than stage 3 , signifying that terpenoid metabolism is involved in the growth and development of celery (Li et al., 2020). 
It is difficult to predict the flavour profile of a crop at the point of consumption as multiple factors and interactions between the environment and genotype will contribute to any variations that may occur. Although the genotype will determine the capacity of the crop to synthesise the chemical components of the flavour profile, environmental factors play an important role in determining the phenotype (or chemotype). This in turn influences flavour, causing crops of the same variety to develop different secondary metabolite profiles such as polyphenols and volatiles, in different growing environments (Raffo, Sinesio, Moneta, Nardo, Peparaio \& Paoletti, 2006). A response to abiotic stress is to synthesise aromatic compounds that protect the crop, which ultimately affects postharvest quality (Yan, $\mathrm{Yu}, \mathrm{Xu}$, Gu \& Zhu, 2014). This means that edge effects in the field can impact on volatile content. Crop plants grown on the borders of the field may exhibit a different volatile content to individuals of the same cultivar grown in the middle of the field, where there is more protection from pests and unfavourable weather conditions. Short chain aldehydes and alcohols $\left(\mathrm{C}_{6}\right.$ and $\left.\mathrm{C}_{9}\right)$ are known to be produced by plants in response to wounding occurring during harvest and storage. These compounds are GLVs and are important contributors to the characteristic aroma of celery but also play an important role in the plant defence strategies though intra and interplant volatile signalling. The evidence suggests that once damage has occurred, GLVs form, released and detected by other plants, evoking a defence system in response (Matsui, 2006; Scala, Allmann, Mirabella, Haring \& Schuurink, 2013).

A study carried out by Yan et al. (2014) showed that celery grown in soil in a drier climate or 'more stressful' environment could impose a higher bitterness through increased polyphenols to protect the crop against abiotic and biotic stresses. Yan et al. (2014) utilised a deep sequencing method to identify how miRNAs interact under heat stress, recognising that, although different varieties of celery have similar morphology, the miRNA population being expressed in order to withstand biotic and abiotic factors of their surroundings (Yan et al., 2014). Furthermore, the colour of the petiole can be manipulated through placement of planting and white celery can be produced by planting seeds in a shaded area. Here, the crop is away from direct sunlight and thus the production of chlorophyll is inhibited, and the crop remains white in colour (Sowbhagya, 2014). 
Exposure to alternative environmental conditions and sequencing the genes expressed will help identify which parts of the genome respond to different environmental stimuli such as; soil composition, season and climate (Stoop \& Pharr, 1994). From this, it can be identified which genes expressed are also connected to flavour compounds.

D'Antuono, Neri \& Moretti (2002) found that changing the nitrogen levels in the soil can lead to a change in the flavour profile of celery. Using the cultivar Darklet and varying nitrogen concentrations, they found that higher doses of nitrogen led to a higher sedanenolide and lower monoterpene (limonene) content (D'Anutono, Neri \& Moret). Thappa et al. (2003) reported that a high limonene content may lead to an unpalatable celery and a celery exhibiting higher phthalide content can be more desirable. Conversely, the application of nitrogen fertiliser on celery crop was shown to have a negative influence over the volatile composition of the crop, as identified by van Wassenhove, Dirinck, Schamp \& Vulsteke (1990). Applying organic and mineral nitrogen fertiliser to two different varieties of celery saw a large decrease in the volatile content, particularly in the phthalide compounds.

Furthermore, the influence of irrigation on the chemical composition of the essential oil of $A$. graveolens was investigated by Rożek, Nurzyńska-Wierdak, Sałata, \& Gumiela (2016), whereby an increase in a range of monoterpenes ( $\alpha$-pinene, cymene, limonene) can be seen in the petioles. However, a decrease can be seen in compounds such as myrcene, caryophyllene and (Z)- $\beta$-ocimene. In terms of phthalides, only $(Z)$-ligustilide was identified in the petioles of celery at $0.05 \%$ when no irrigation was used, it could not be identified when irrigation was applied (Rożek et al., 2016).

On the other hand, Khalid \& Hussein (2012) investigated the effect of cattle and liquid manures on the essential oil content of celery grown at the Experimental Farm of National Research Centre, Egypt across two seasons. The essential oil was extracted using hydrodistillation and analysed using GC/MS. Overall, statistical differences were observed when using a liquid manure and it was concluded that the use of a combination of liquid and cow manure gave the "best essential oil production". Although an increase in the phthalide content was witnessed, a closer look shows that there was no statistically significant change and in fact there was a decrease in the monoterpene content. An increase in acetate esters including trans-pinocarvyl acetate and cis-carvyl acetate can be seen, as well as in 
512 there was a positive influence on the essential oil content (\%) and yield when using liquid and cow

513 manures, there was minimal influence on the essential oil constituents and the impact these manures

514 had on the flavour profile could be questioned (Kokotkiewicz and Luczkiewicz, 2016).

Finally, the time of harvest could have an influence on the aroma of celery, although it has been shown that this is only minimal. Lund et al. (1973) were able to show seasonal and varietal differences from the oils recovered from celery waste from a packinghouse in Florida, using two varieties and taking waste trimmings and stalks in different seasons (November, April and July). A slight difference was observed in the composition of the waste trimmings from all cuts; sedanolide and $\beta$-selinene, identified as important compounds to the celery odour in this study and exhibited a decrease from 3.09\% and $4.00 \%$ in November to $2.68 \%$ and $3.67 \%$ in April respectively. Limonene was not detected at all in the April harvest. Lund et al. (1973) attributed this difference to the higher proportion of stalks in the waste in April rather than leaf trimmings and concluded that using an oil with a higher leaf content leads to a better quality of oil for flavouring. Varietal differences are more obviously observed, whereby compounds marked as celery-like odour compounds are shown to either be lower or not detected in the second variety used in this study, it can be expected that this variety will have a less "typical" celery odour.

\section{Post-harvest environment and the aroma of celery}

The flavour of the crop can be influenced post-harvest due to poor harvesting techniques, incorrect handling or storage conditions. The optimum storage conditions for celery include a temperature of 0 ${ }^{\circ} \mathrm{C}$ with a high relative humidity of $95 \%$ (Malhotra, 2012). This maintains the desired organoleptic properties and appearance qualities over storage, however when the temperature is increased to $10{ }^{\circ} \mathrm{C}$, these desired properties start to change. Viña and Chaves (2003) studied the textural differences and changes in fresh cut celery stored at $0{ }^{\circ} \mathrm{C}$ and $10{ }^{\circ} \mathrm{C}$ for 27 days. Sampling occurred at day $0,7,14,21$ and 27. Firstly, after seven days, strong yellow discolouration of the petioles was witnessed, and texture 
changes described as a "loss of crispiness" occurred. They further acknowledged the development of "off-odours" when samples were stored at $10{ }^{\circ} \mathrm{C}$ for 21 days, accompanied by rot and micro-organism decay. Twenty-one days is not a typical duration for the supply chain and these senescence characteristics would not be experienced by the consumer. Furthermore, this assessment was only completed through visual inspection (Viña \& Chaves, 2003). It is likely that these off-odours were produced earlier on in the experiment, but not at a noticeable level to be detected by the human nose until day 21. Without the use of a fully trained nose, this becomes a very subjective method of monitoring organoleptic property changes. Using a GC/MS method would confirm the presence and identification of the off odours that were produced.

Preservation methods such as drying (freeze-drying and convection drying) and their influence on the aroma profile on the essential oil of two cultivars of celery were investigated by NurzyńskaWierdak, Gruszeck \& Kosior (2018). Using convection drying, a larger number of compounds were retained including limonene and $\beta$-selinene, whereas freeze-drying allowed a higher retention of myrcene. The effect of drying on the phthalide content is unclear as they were not identified in either cultivars. Although it is clear that harvest time and cultivar used had an impact on the essential oil content, they concluded that convection drying allows for a higher yield of essential oil than freezedrying (Nurzyńska-Wierdak, Gruszecki, \& Kosior, 2018). Overall, freezing has been shown as the optimum preservation method in terms of retaining the volatile constituents of celery essential oil when comparing to fresh celery (Rolson, Osińska and Gajc-Wolska, 2012; Roslon, Osińska, \& WajsBonikowska, 2013; Kokotkiewicz and Luczkiewicz, 2016).

It is known that vegetables belonging to the Apiaceace family are capable of synthesising furanocoumarins, these being responsible for the production of off-odours, due to unfavourable conditions such as UV radiation, temperature changes and bacterial infections (Chaudhary, Ceska, Warrington \& Ashwood-Smith, 1985). Furanocoumarins are secondary metabolites present in a limited number of plant families including: Moraceae, Apiaceae and Rutaceae and are involved in plant defence and environmental adaptation (Dugrand-Judek et al., 2015). Chaudhary et al. (1985) identified levels of furocoumarins was at its highest in celery that showed signs of fungal infections after 22 to 29 days 
of storage. There was a statistically significant increase in the levels of 5-methoxypsoralen, 8-

565 methoxypsoralen and psoralen compared with fresh celery. These furocoumarins are defence

566 compounds with antimicrobial properties, synthesised in response to the biotic stress (Chaudhary et al.,

567 1985).

568 A review completed by Forney (2008) identified processes during postharvest handling on fresh569 cut produce that caused significant flavour loss. Forney identified two kinds of mechanisms that cause 570 flavour loss, the first being metabolic changes due to the synthesis of flavour compounds and these 571 could be off odours as well. Metabolic changes are subject to the crop physiology, which in turn is 572 influenced mainly by environmental factors. The second mechanism is diffusional changes in product 573 flavour, whereby the volatile compounds transfer out of the crop. Where metabolic changes are 574 dependent on the plant physiology, diffusional changes are reliant on the chemical and physical 575 properties of the flavour compound itself. The determination of the flavour of celery post-harvest is 576 dependent on these two mechanisms which in turn, are dependent on the environment in which the crop 577 is kept (Forney, 2008). 


\section{Conclusion}

580

581

582

583

584

585

586

587

588

589

590

591

592

593

594

595

596

597

598

599

600

601

602

603

Using the data that has been collated in Table 3, showing the aroma compounds in various celery varieties, it can be seen that the aroma profile of celery is complex, consisting of an assortment of compounds ranging from terpenes and phthalides to alcohols and aldehydes. Terpenes and phthalides are most consistently reported throughout literature, with less emphasis placed upon other compounds such as alcohols, esters and aldehydes. However, this does not mean the latter are any less significant contributors to the aroma of celery.

Given the vast amount of work that has been already completed, there is rarely a dataset that states the variety of celery used, the season and location in which it was sampled and whether repetitions were completed over multiple time points in multiple sites. Therefore, very few papers provide insight into the aromatic variance that may be attributed to environmental factors, as distinguished to those due to the genetic influence of variety. When the cultivar variety is specified, it is clear that there is an impact of genetics on aroma, since all sources express different aroma compounds. Providing minimal standardised information such as geographical location of growth and cultivar could help build a bigger and better library to help understand the impact these factors have upon the aroma profile of celery and we recommend the adoption of MIAPAE standards for flavour and aroma publications on all crops.

Preference of celery flavour by consumers is an area that needs further investigation to help improve the quality of celery that is produced, alongside an understanding of how the postharvest environment further changes the organoleptic profile of the crop as it moves through the supply chain. Furthermore, linking sensory profiling and consumer liking with flavour chemistry is an untouched topic and making this connection will provide information for producers and retailers on how celery quality is perceived and how important sensory attributes, such as flavour and aroma, are to influencing consumer preference. The availability of the celery genome sequence now makes targeted breeding for these biochemically driven traits a realistic possibility for vegetable plant breeders to pursue so that lines can be developed that have distinct flavour profiles. 


\section{References}

Bartschat, D., Beck, T., \& Mosandl, A. (1997). Stereoisomeric Flavor Compounds. 79. Simultaneous Enantioselective Analysis of 3-Butylphthalide and 3-Butylhexahydrophthalide Stereoisomers in Celery, Celeriac, and Fennel. Journal of Agricultural and Food Chemistry, 45(12), 4554-4557. https://doi.org/10.1021/jf970491f

Brazma, A., Hingamp, P., Quackenbush, J., Sherlock, G., Spellman, P., Stoeckert, C., Aach, J., Ansorge, W., Ball, C., Causton, H., Gaasterland, T., Glenisson, P., Holstege, F., Kim, I., Markowitz, V., Matese, J., Parkinson, H., Robinson, A., Sarkans, U., Schulze-Kremer, S., Steward, J., Taylor, R., Vilo, J., \& Vingron, M. (2001). Minimum information about a microarray experiment (MIAME) - Toward standards for microarray data. Nature Genetics, 29(4), 365-371. https://doi.org/10.1038/ng1201-365

Chaudhary, S., Ceska, O., Warrington, P., \& Ashwood-Smith, M. (1985). Increased Furocoumarin Content of Celery during Storage. Journal of Agricultural and Food Chemistry, 33(6). https://doi.org/10.1021/jf00066a032

Deng, C., Song, G., Zheng, X., Hu, Y., \& Xiangmin, Z. (2003). Analysis of the Volatile Constituents of Apium graveolens L. and Oenanthe L. by Gas Chromatography-Mass Spectrometry, Using Headspace Solid-Phase Microextraction. Chromatographia. 57(11-12). 80-809. https://doi.org/10.1007/BF02491769

Ehiabhi, O., Edet, U., Walker, T., Schmidt, J., Setzer, W., Ogunwande, I., Essien, E. \& Ekundayo, O. (2006). Constituents of Essential Oils of Apium graveolens L., Allium cepa L., and Voacanga africana Staph. from Nigeria. Journal of Essential Oil Bearing Plants. 9(2), 126132. https://doi.org/10.1080/0972060X.2006.10643483

Forney, C. (2008). Flavour loss during postharvest handling and marketing of fresh-cut produce. Stewart Postharvest Review, 4(3), 1-10. https://doi.org/10.2212/spr.2008.3.5

Gold, H., \& Wilson, C. (1963). The Volatile Flavor Substances of Celery. Journal of Food Science, 28(4), 484488. https://doi.org/10.1111/j.1365-2621.1963.tb00231.x

Jian-Qin, C., Zheng-Ju, Z., Fan, P., Perineau, F., Delmas, M. \& Gaset, A. (1990). GC/MS and GC/FTIR analysis of the essential oil of celery seed. Journal of Essential Oil Research, 2(1), 1-5. https://doi.org/ 10.1080/10412905.1990.9697808

Karmakar, R., Pahari, P., \& Mal, D. (2014). Phthalides and Phthalans: Synthetic Methodologies and Their Applications in the Total Synthesis, 114(12), 6213-6284. https://doi.org/10.1021/cr400524q

Khalid, K., \& Hussein, M. (2012). Effect of cattle and liquid manures on essential oil and antioxidant activities of celery (apium graveolens 1.) fruits. Journal of Essential Oil-Bearing Plants, 15(1), 97-107. https://doi.org/10.1080/0972060X.2012.10644025

Kokotkiewicz, A. \& Luczkiewicz, M. (2016). Celery (Apium graveolens var. dulce (Mill.) Pers.) Oils. Essential Oils in Food Preservation, Flavor and Safety. Elsevier Ltd.

Kurobayashi, Y., Kouno, E., Fujita, A., Morimitsu, Y., \& Kubota, K. (2006). Potent Odorants Characterize the Aroma Quality of Leaves and Stalks in Raw and Boiled Celery. Bioscience, Biotechnology, and Biochemistry, 70(4), 958-965. https://doi.org/10.1271/bbb.70.958

Kuzuyama, T., \& Seto, H. (2012). Two distinct pathways for essential metabolic precursors for isoprenoid biosynthesis. Proceedings of the Japan Academy, Series B , 88(3), 41-52. https://doi.org/10.2183/pjab.88.41 
Li, M.-Y., Hou, X.-L., Wang, F., Tan, G.-F., Xu, Z.-S., \& Xiong, A.-S. (2018). Advances in the research of celery, an important Apiaceae vegetable crop. Critical Reviews in Biotechnology, 38(2), 172-183. https://doi.org/10.1080/07388551.2017.1312275

651

Li, M., Feng, K., Hou, X., Jiang, Q., Xu, Z., Wang, G. \& Xiong,. S. (2020). The genome sequence of celery (Apium graveolens L.), an important leaf vegetable crop rich in apigenin in the Apiaceae family. Horticulture Research, 7(1). https://doi.org/10.1038/s41438-019-0235-2

Lin, G., Chan, S., Chung, H. \& Li, S. (2005). Chemistry and biological activities of naturally occurring phthalides. Studies in Natural Products Chemistry, 32(PART L), 611-669. https://doi.org/10.1016/S1572-5995(05)800651

Lund, E., Wagner, C. \& Bryan, W. (1974). Oils recovered from celery packinghouse waste. Florida State Horticultural Society. $86.255-259$

Macleod, A., MacLeod, G., \& Subramanian, G. (1988). Volatile Aroma Constituents of celery. Phytochemistry, 27(2), 373-375.

MacLeod, G., \& Ames, J. (1989). Volatile components of celery and celeriac. Phytochemistry, 28(7), 1817-1824. https://doi.org/10.1016/S0031-9422(00)97866-X

Malhotra, S. (2012). Celery. Handbook of Herbs and Spices: Second Edition, 2, 249-267. https://doi.org/10.1533/9780857095688.249

Marongiu, B., Piras, A., Porcedda, S., Falconieri, D., Maxia, A., Frau, M., Gonçalves, M., Cavaleiro, C. \& Salgueiro, L. (2013). Isolation of the volatile fraction from Apium graveolens L. (Apiaceae) by supercritical carbon dioxide extraction and hydrodistillation: Chemical composition and antifungal activity. Natural Poduct Research. 27(17), 1521-1527. https://doi.org/10.1080/14786419.2012.725402

Matsui, K. (2006). Green leaf volatiles: hydroperoxide lyase pathway of oxylipin metabolism. Current Opinion in Plant Biology, 9(3), 274-280. https://doi.org/10.1016/j.pbi.2006.03.002

Nurzyńska-Wierdak, R., Gruszecki, R., \& Kosior, M. (2018). Does preservation modify the essential oil content and chemical composition of leaf celery (Apium graveolens L. var. secalinum alef.)? Acta Scientiarum Polonorum, Hortorum Cultus, 17(6), 27-36. https://doi.org/10.24326/asphc.2018.6.3

Orav, A., Kailas, T., \& Jegorova, A. (2003). Composition of the essential oil of dill, celery, and parsley from Estonia. Proceedings of the Estonian Academy of Sciences. Chemistry, 54(4), 147-154.

Oreopoulou, A., Tsimogiannis, D. \& Oreopoulou, V. (2019). Extraction of polyphenols from aromatic and medicinal plants: An overview of the methods and the effect of extraction parameters. Polyphenols in Plants. Elsevier Ltd. https://doi.org/10.1016/B978-0-12-813768-0.00025-6

Parker, J. (2015). Introduction to aroma compounds in foods. Flavour Development, Analysis and Perception in Food and Beverages. Elsevier Ltd. https://doi.org/10.1016/B978-1-78242-103-0.00001-1

Philippe, J., Suvarnalatha, G., Sankar, R., \& Suresh, \& S. (2002). Kessane in the Indian Celery Seed Oils. Journal of Essential Oil Research, 14(4), 276-277. https://doi.org/10.1080/10412905.2002.9699852

Pichersky, E., \& Gershenzon, J. (2002). The formation and function of plant volatiles: Perfumes for pollinator attraction and defense. Current Opinion in Plant Biology, 5(3), 237-243. https://doi.org/10.1016/S13695266(02)00251-0

Plotto, A., Margaría, C., Goodner, K., Goodrich, R., \& Baldwin, E. (2004). Odour and flavour thresholds for key aroma components in an orange juice matrix: Terpenes and aldehydes. Flavour and Fragrance Journal, 19(6), 491-498. https://doi.org/10.1002/ffj.1470

Raffo, A., Sinesio, F., Moneta, E., Nardo, N., Peparaio, M., \& Paoletti, F. (2006). Internal quality of fresh and cold stored celery petioles described by sensory profile, chemical and instrumental measurements. European Food Research and Technology, 222(5-6), 590-599. https://doi.org/10.1007/s00217-005-00987

Roslon, W., Osińska, E., \& Wajs-Bonikowska, A. (2013). Effect of plantation establishment and raw material stabilization on the usefull traits of lovage leaves (Levisticum officinale koch.). Acta Scientiarum Polonorum, Hortorum Cultus, 12(1), 141-155.

Rowan, D. (2011). Volatile metabolites. Metabolites, 1(1), 41-63. https://doi.org/10.3390/metabo1010041 
Rozek, E. (2007). Growth and yielding of leaf celery (Apium graveolens L.var secalinum Alef.) cultivated for two-cut harvests. Herba Polonica , 53(3), 17-21.

Rożek, E., Nurzyńska-Wierdak, R., Sałata, A., \& Gumiela, P. (2016). The chemical composition of the essential oil of leaf celery (Apium graveolens 1. var. Secalinum Alef.) under the plants' irrigation and harvesting method. Acta Scientiarum Polonorum, Hortorum Cultus, 15(1), 147-157.

Sellami, I., Bettaieb, I., Bourgou, S., Dahmani, R., Limam, F. \& Marzouk, B. (2012). Essential oil and aroma composition of leaves, stalks and roots of celery (Apium graveolens var. dulce) from Tunisa. Journal of Essential Oil Research. 24(6), 513-521. http://dx.doi.org/10.1080/10412905.2012.728093

Schwab, W., Davidovich-Rikanati, R., \& Lewinsohn, E. (2008). Biosynthesis of plant-derived flavor compounds. Plant Journal, 54(4), 712-732. https://doi.org/10.1111/j.1365-313X.2008.03446.X

Shojaei, Z., Ebrahimi, A., \& Salimi, M. (2011). Chemical composition of three ecotypes of wild celery (Kelussia odoratissima). Journal of Herbs, Spices and Medicinal Plants, 17(1), 62-68. https://doi.org/10.1080/10496475.2011.560089

Sorour, M., Hassanen, N. \& Ahmed, M. (2015). Natural antioxidant changes in fresh and dried celery (Apium graveolens). American Journal of Energy Engineering. 3(2-1), 12-16. https://doi.org/10.11648/j.ajee.s.2015030201.13

Sowbhagya, H. (2014). Chemistry, Technology, and Nutraceutical Functions of Celery (Apium graveolens L.): An Overview. Critical Reviews in Food Science and Nutrition, 54(3), 389-398. https://doi.org/10.1080/10408398.2011.586740

Stoop, J. \& Pharr, D. (1994). Growth Substrate and Nutrient Salt Environment Alter Mannitol-to-Hexose Partitioning in Celery Petioles. Journal of the American Society for Horticultural Science, 119(2), 237-242. https://doi.org/10.21273/JASHS.119.2.237

Stumpe, M., \& Feussner, I. (2006). Formation of oxylipins by CYP74 enzymes. Phytochemistry Reviews, 5(2-3), 347-357. https://doi.org/10.1007/s11101-006-9038-9

Tang, J., Zhang, Y., Hartman, T., Rosen, R. \& Ho, C-T. (1990). Free and Glycosidically Bound Volatile Compounds in Fresh Celery (Apium graveolens L.). Journal of Agricultural and Food Chemistry. 38(10). 1937-1940. https://doi.org/10.1021/jf00100a013

Terry, L. (1989). Understanding the mechanisms and the role that preharvest horticultural maturity, agronomic factors and growing conditions have on postharvest discolouration in celery . Horticultural Development Company CP79 CRANFIELD HEALTH Student: Anastasia Fountoul. Horticultural Development Company, 1-37.

Uhlig, J., Chang, A., \& Jen, J. (1987). Effect of Phthalides on Celery Flavor. Journal of Food Science (Vol. 52). https://doi.org/10.1111/j.1365-2621.1987.tb06696.x

van Wassenhove, F., Dirinck, P., Vulsteke, G., \& Schamp, N. (1990). Aromatic volatile composition of celery $\begin{array}{llll}\text { and celeriac } & \text { cultivars. } & \text { HortScience, } & \text { 25(5), }\end{array}$ https://doi.org/https://doi.org/10.21273/HORTSCI.25.5.556

van Wassenhove, F., Dirinck, P., Vulsteke, G., \& Schamp, N. (1990). Effect of nitrogen fertilizers on celery volatiles. Journal of Agricultural and Food Chemistry.38(1). 220-226. https://doi.org/10.1021/jf00091a049

Victório, C., Riehl, C., da S., \& Lage, C. (2009). Simultaneous Distillation-Extraction, Hydrodistillation and Static Headspace Methods for the Analysis of Volatile Secondary Metabolites of Alpinia zerumbet (Pers.) Burtt et Smith. from Southeast Brazil. Journal of Essential Oil-Bearing Plants, 12(2), 137-143. https://doi.org/10.1080/0972060X.2009.10643703

Viña, S., \& Chaves, A. (2003). Texture changes in fresh cut celery during refrigerated storage. Journal of the Science of Food and Agriculture, 83(13), 1308-1314. https://doi.org/10.1002/jsfa.1540

Wilson, C. (1967). Identification and Quantitative Estimation of Alcohols in Celery Essential Oil. Journal of Food Science, 34, 535-537. https://doi.org/10.1111/j.1365-2621.1969.tb12081.x

Wilson, C. (1970). Relative recovery and identification of carbonyl compounds from celery essential oil. Journal of Food Science. 35(6), 766-768. https://doi.org/ 10.1111/j.1365-2621.1970.tb01989.x

Wolski, T., Najda, A. \& Hołderna-Kędzia, E. (2004). Content and composition of essenial oils and extracts obtained from fruit of selected plants from Umbelliferae (Apiaceae) family with preliminary antibacterial 
estimation of extracts. Advances in Phytotherapy, 3, 119-125.

748 Yan, J., Yu, L., Xu, S., Gu, W., \& Zhu, W. (2014). Apigenin accumulation and expression analysis of apigenin

749 biosynthesis relative genes in celery. Scientia Horticulturae, 165, 218-224.

$750 \quad$ https://doi.org/10.1016/j.scienta.2013.11.018

751 
Figure 1: A range of volatile compounds that occur and contribute to the typical aroma of celery; isoprene (A), limonene (B), $\beta$-pinene (C), $\beta$ selinene (D), $\beta$-caryophyllene $(\mathrm{E}), 1(3 \mathrm{H})$-isobenzofuranone $(\mathrm{F})$, butylphthalide $(\mathrm{G})$, 3-butylidenephthalide $(\mathrm{H})$, (Z)-ligustilide (I), sedanenolide (J), (Z)-3-hexenyl pyruvate (K), (Z)-3-hexen-1-ol (L), linalool (M) and (Z)-3-hexenal (N).
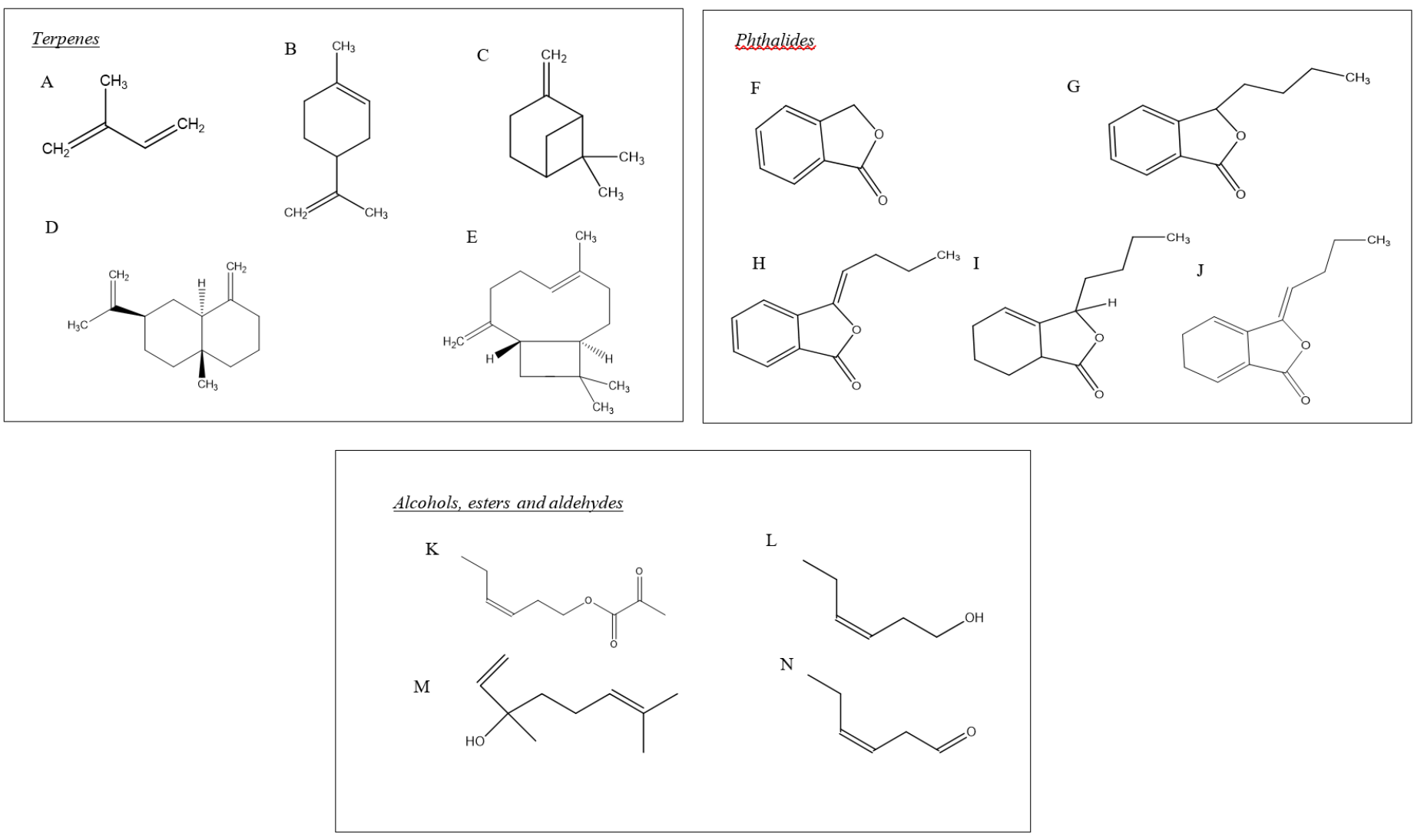
Appendix 1. Schematic 1: Mevalonate Pathway for IPP and DMAPP synthesis

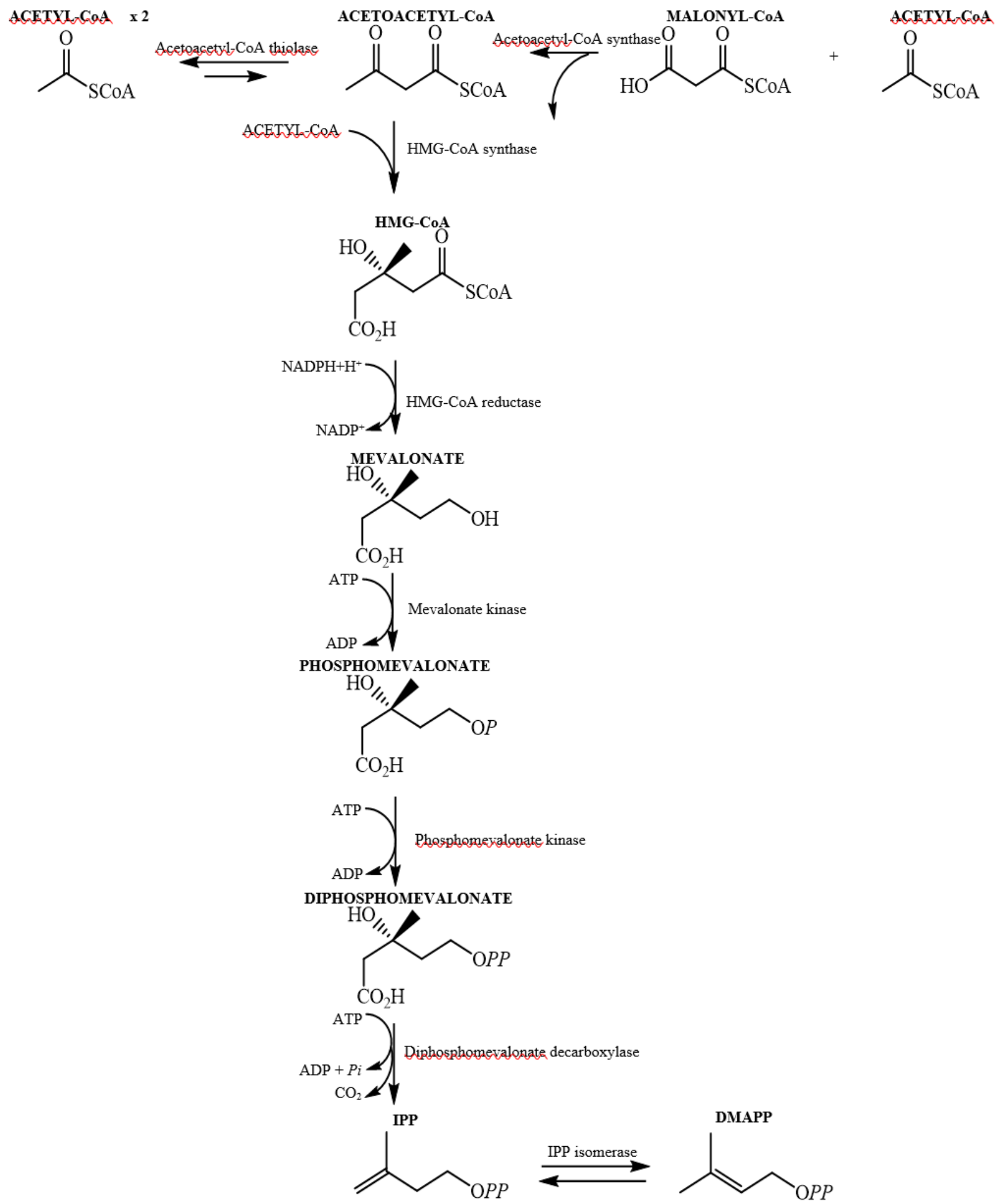


Appendix 1. Schematic 2 - Non-mevalonate pathway for IPP and DMAPP synthesis

$$
\text { PYRUVATE }
$$

GAP

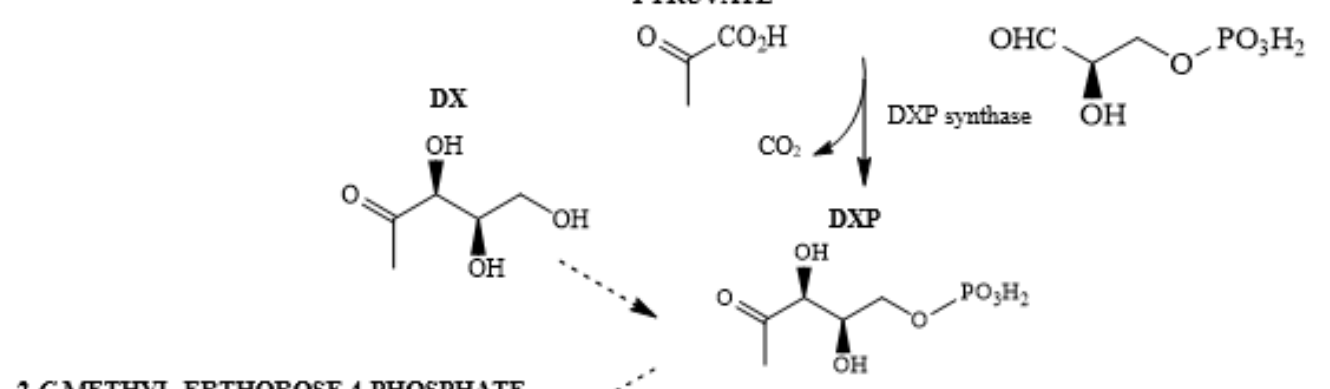

\section{2-C-METHYL-ERTHOROSE 4-PHOSPHATE}
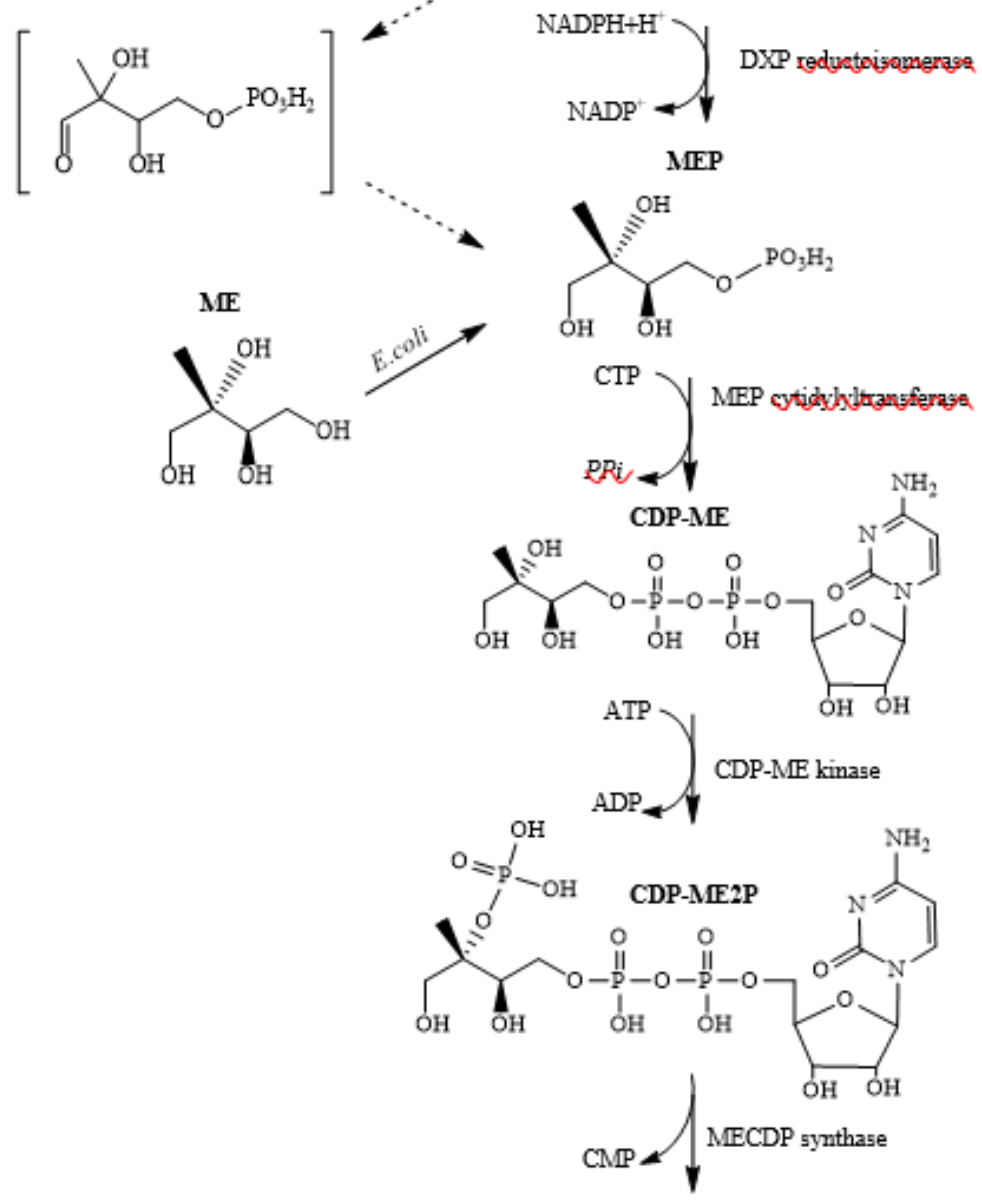

MECDP
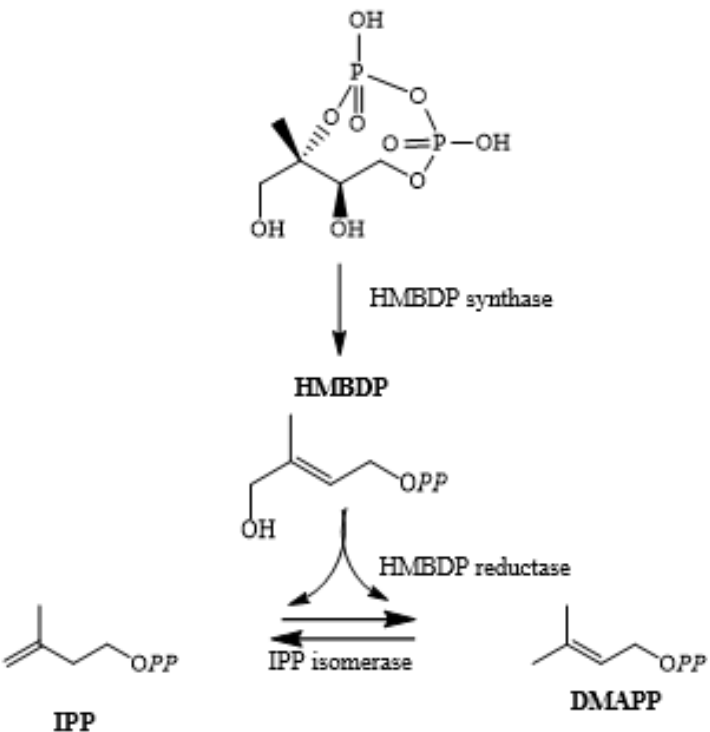
Appendix 1. Schematic 3-Phthalide, synthesis

1.<smiles>CC(=O)O</smiles>

2.

Polyketide synthases

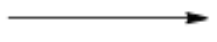

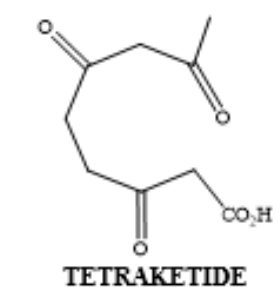

TETRAKETIDE

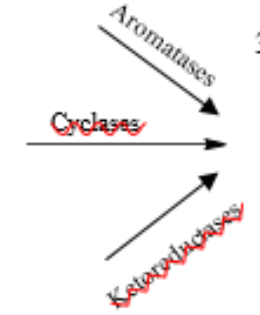

3. $\mathrm{HO}$<smiles>[2H]c1cc(C)c(C(=O)O)c(O)c1</smiles>

ORSELLINIC ACID
4.<smiles>Cc1c(C)c(C(=O)O)c(O)c(C)c1O</smiles>

7.<smiles>Cc1c(C)c(C(=O)O)c(C(=O)O)c(C=O)c1C=O</smiles>

5.<smiles>Cc1c(O)c(C)c(C=O)c(C(=O)O)c1O</smiles>

8.<smiles>CCOc1cc(C=O)c(C=O)c(C=O)c1C</smiles>

DIALDEHYDE<smiles>Cc1c(C=O)c(C=O)c(C=O)c(C(=O)O)c1C(=O)O</smiles><smiles>Cc1c(O)cc(C(=O)O)c(CO)c1C(=O)O</smiles>

10.

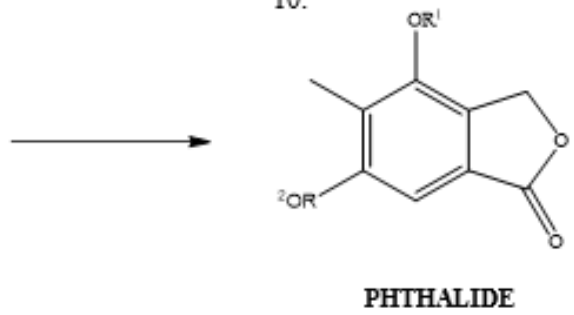

